\title{
Toxicity of four metals and their mixtures to Pseudomonas fluorescens: An assessment using fixed ratio ray design
}

\author{
Nweke, C.O.*, Umeh, S.I. \& Ohale V.K. \\ Department of Microbiology, Federal University of Technology, P.M.B.1526, Owerri, Nigeria.
}

Receive December 20, 2016; Accept February 16, 2018

\begin{abstract}
The toxicities of binary (Ni(II) $+\mathrm{Co}(\mathrm{II})$ and $\mathrm{Zn}(\mathrm{II})+\mathrm{Cd}(\mathrm{II}))$, ternary $(\mathrm{Zn}(\mathrm{II})+\mathrm{Cd}(\mathrm{II})+\mathrm{Ni}(\mathrm{II})$ and $\mathrm{Ni}(\mathrm{II})+\mathrm{Co}(\mathrm{II})+\mathrm{Cd}(\mathrm{II}))$ and quaternary (Ni(II) $+\mathrm{Co}(\mathrm{II})+\mathrm{Zn}(\mathrm{II})+\mathrm{Cd}(\mathrm{II}))$ mixtures of metal ions to Pseudomonas fluorescens were assessed by using inhibition of dehydrogenase activity as an endpoint. Uniform design concentration ratio (UDCR) and equieffect concentration ratio (EECR) mixtures were designed to evaluate the combined toxicities of these heavy metal ions. All the dose-response relationships of the UDCR and EECR mixtures and the individual metals could be described by logistic function. Toxicities predicted by concentration addition (CA) and independent action (IA) models were compared with the observed toxicities. The CA and IA models predicted similar toxicities of the binary and $\mathrm{Zn}(\mathrm{II})+\mathrm{Cd}(\mathrm{II})+\mathrm{Ni}$ (II) ternary mixtures. Generally, $\mathrm{Zn}$ (II) $+\mathrm{Cd}(\mathrm{II})+\mathrm{Ni}(\mathrm{II})$ ternary mixtures were synergistic while $\mathrm{Ni}(\mathrm{II})+\mathrm{Co}(\mathrm{II})+\mathrm{Cd}(\mathrm{II})$ ternary mixtures were antagonistic. The equieffect and quaternary mixtures were generally synergistic. Synergistic, antagonistic and additive effects of the mixtures are possible from the viewpoint of these analyses.
\end{abstract}

Keywords: Heavy metals, dehydrogenase activity, concentration addition model, independent action model.

\section{INTRODUCTION}

Heavy metals are widespread pollutants of great concern because they are non-degradable and thus persistent (Jansen et al., 1994). Although heavy metals are naturally occurring elements, most environmental contaminations result from human activities such as mining and smelting operations, industrial production, domestic and agricultural use of metals. Industrial effluents are discharged into the environment and thus exposing humans, animals and microorganisms to the harmful effects of metal pollutants. Some heavy metals (such as $\mathrm{Zn}, \mathrm{Co}, \mathrm{Cu}$ and $\mathrm{Ni}$ ) are essential trace elements required for normal physiological function of microorganisms. They serve as micronutrients and are used for redox processes to stabilize molecules, as components of enzymes and for regulation of osmotic pressure (Bruins et al., 2000). However, at high concentrations, these essential metals can be inhibitory to microbial processes. Other heavy metals (such as $\mathrm{Cd}, \mathrm{Hg}$ and $\mathrm{Pb}$ ) have no physiological function and are toxic even at low concentrations.
Heavy metals generally exert toxicity in microorganisms by blocking essential functional groups, displacing essential metal ions or modifying the active conformation of biomolecules (Wood et al., 1983), denaturing and inactivating enzymes and disrupting cell membrane integrity (Gadd, 1993). Given that microorganisms respond promptly to environmental pollution, factors affecting their metabolism and diversity are of great importance. Therefore, toxicity tests using living organisms constitute a vital part of environmental monitoring (Awasthi, 2012).

Metals as contaminants rarely occur in isolation (Gikas, 2008). Cadmium, zinc, cobalt and nickel are widely used in many industrial processes and thus exist as cocontaminants in the environment (Nies, 1992). It is more suitable and advantageous to study their interactive effects in the environment. The combined toxic effects of multiple chemicals are recognized as an important consideration in ecotoxicology because mixtures of chemicals can possibly induce synergistic effects (McCarty \& Borgert, 2006). Thus, in order to determine the ecotoxicological implications of

*Corresponding author: C. O. Nweke; e-mail: xrisokey@yahoo.com 
metal contamination of natural environment, it is important to evaluate the joint effects of metal mixtures on natural biota. Such assessment requires sensitive, rapid, cheap and reliable toxicity test. In this regard, different microbial parameters such as growth rate (Juliastuti et al., 2003), biomass measurement (Guckert, 1996), inhibition of bioluminescence (Ren \& Frymier, 2003; Ince et al., 1999; Preston et al., 2000; Fulladosa et al., 2005) and activity of enzymes (Bitton et al., 1992) have been adopted to evaluate toxic effects of metals on microbial population. Investigations on the toxicity of metal mixtures have mainly based on inhibition of bacterial bioluminescence.

In this study, fixed ratio ray design was used to evaluate the interactive effects of binary, ternary and quaternary mixtures of $\mathrm{Cd}(\mathrm{II}), \mathrm{Zn}(\mathrm{II}), \mathrm{Co}(\mathrm{II})$ and $\mathrm{Ni}(\mathrm{II})$ ions on Pseudomonas fluorescens based on inhibition of dehydrogenase activity. $P$. fluorescens is an environmentally-important bacterium that is ubiquitously distributed in soil and water. It has diverse metabolic capabilities and grows in minimal media supplemented with wide range of carbon sources and has found a number of applications in the area of bioremediation (Richard \& Vogel, 1999; Bugg et al., 2000), control of plant pathogens and plant growth promotion (Ganeshan \& Kumar, 2005; Sivasakthi et al., 2013). Thus, studying the factors that influence the metabolic activities of the organism is important. Such factors include many inorganic and organic pollutants that found their way into the environment via anthropogenic and natural sources.

\section{MATERIALS AND METHODS}

\section{Metal ions and reagents}

The Ni(II), $\mathrm{Cd}(\mathrm{II}), \mathrm{Co}(\mathrm{II})$ and $\mathrm{Zn}(\mathrm{II})$ ions were used as $\mathrm{NiSO}_{4} \cdot 6 \mathrm{H}_{2} \mathrm{O}, \mathrm{CdSO} 4.8 / 3 \mathrm{H}_{2} \mathrm{O}, \mathrm{CoCl}_{2}$ and $\mathrm{ZnSO}_{4} \cdot 7 \mathrm{H}_{2} \mathrm{O}$. Stock solutions of $10 \mathrm{mM}$ of the individual metal ion were prepared in deionized distilled water. Working stock solution of $1 \mathrm{mM}$ $\mathrm{Cd}$ (II) was prepared by diluting the $10 \mathrm{mM}$ stock $1 / 10$ with deionized distilled water. The 2,3,5-triphenyltetrazolium chloride (TTC) was purchased from Sigma (Germany). All reagents are of analytical grade.

\section{Test organism}

The test bacterium Pseudomonas fluorescens was isolated from soil on Pseudomonas agar for fluorescein (Sisco Research Laboratories (SRL), Mumbai, India). The organism fluoresces green under ultraviolet light on Pseudomonas agar. The identity of the bacterium was further confirmed by oxidase production, oxidative fermentation, growth at $4{ }^{\circ} \mathrm{C}$, no growth at $42^{\circ} \mathrm{C}$, nitrate reduction, phosphate solubilization (using Pikovskaya's broth, SRL, India), acid production from mannitol and maltose.

The bacterium was grown to mid exponential phase in nutrient broth (Lab M) on a rotary incubator $(150 \mathrm{rpm})$ at room temperature $\left(28 \pm 2^{\circ} \mathrm{C}\right)$ and the cells harvested by centrifugation at $3000 \mathrm{rpm}$ for $10 \mathrm{~min}$. Harvested cells were washed twice in sterile deionized distilled water to avoid any nutrient carryover. Washed cells were re-suspended in sterile deionized distilled water and the optical density adjusted to 0.1 at $540 \mathrm{~nm}$. The cell suspensions were used as inoculum in the toxicity assay.

\section{Design of mixture experiments}

The toxicity of the binary mixtures of $\mathrm{Ni}(\mathrm{II})$ and $\mathrm{Co}(\mathrm{II})$ as well as $\mathrm{Zn}$ (II) and $\mathrm{Cd}(\mathrm{II})$ were determined using fixed ratio designs, uniform design concentration ratios (UDCR) and equieffect concentration ratios (EECR). While keeping the mixture ratio constant, the total concentrations of the mixture were varied in order to obtain a complete doseresponse relationship of the mixture. The concentration range of the mixtures was based on the concentration range of the individual metals that gave percent inhibitions ranging from $0 \%$ to $100 \%$ or near $100 \%$. The concentrations of $\mathrm{Ni}(\mathrm{II}), \mathrm{Co}(\mathrm{II})$ and $\mathrm{Zn}$ (II) ranged from 0 to $2 \mathrm{mM}$ while the concentrations of $\mathrm{Cd}(\mathrm{II})$ ranged from 0 to $0.2 \mathrm{mM}$ such that the concentration series of $\mathrm{Cd}(\mathrm{II})$ was one tenth concentration series of $\mathrm{Ni}(\mathrm{II})$, $\mathrm{Co}(\mathrm{II})$ or $\mathrm{Zn}(\mathrm{II})$. The binary mixtures of $\mathrm{Ni}(\mathrm{II})$ and $\mathrm{Co}(\mathrm{II})$ were studied as a function of the following weight to weight ratios: $\mathrm{p}(\%)=80,50$ and 20 , of $\mathrm{Ni}(\mathrm{II})$, and $100-\mathrm{p}(\%)$ of $\mathrm{Co}(\mathrm{II})$ corresponding to $\mathrm{Ni}(\mathrm{II})$ : $\mathrm{Co}(\mathrm{II})$ ratios of: $80: 20 \%, 50: 50 \%$ and 20:80 \%. Similarly, the binary mixtures of Zn(II) and $\mathrm{Cd}(\mathrm{II})$ were studied as a function of the following weight to weight ratios: $\mathrm{p}(\%)=80,50$ and 20 of the concentration series of $\mathrm{Zn}(\mathrm{II})$, and 100-p (\%) of the concentration series of Cd(II) corresponding to $\mathrm{Zn}(\mathrm{II})$ : $\mathrm{Cd}(\mathrm{II})$ ratios of: $80: 20 \%$, 50:50 \% and 20:80 \% based on their respective concentration series. The effective $\mathrm{Zn}(\mathrm{II}): \mathrm{Cd}(\mathrm{II})$ fixed ratios were thus 97.56\% Zn(II):2.44\% Cd(II), 90.91\% Zn(II):9.09\% Cd(II) and $71.43 \% \mathrm{Zn}(\mathrm{II}): 28.57 \% \mathrm{Cd}(\mathrm{II})$ respectively. Additional two different mixture ratios were examined based on the relative toxicity of the individual metals. First, a mixture in which components was mixed in the ratio of the $\mathrm{EC}_{20}$ of the individual metals (referred to as EECR-20 mixture). Second, the toxicity of the mixtures based on $\mathrm{EC}_{50}$ (EECR-50 mixture) of the individual metals were assessed. The EECR-20 and EECR-50 equieffect mixtures of $\mathrm{Ni}(\mathrm{II})$ and $\mathrm{Co}(\mathrm{II})$ yielded effective ratios of $66.06 \% \mathrm{Ni}(\mathrm{II}): 33.94 \% \mathrm{Co}(\mathrm{II})$ and $74.32 \%$ $\mathrm{Ni}(\mathrm{II}): 25.68 \% \mathrm{Co}(\mathrm{II})$ respectively. Similarly, the EECR-20 and EECR-50 equitoxic mixtures of $\mathrm{Zn}$ (II) and $\mathrm{Cd}$ (II) yielded effective ratios of $86.62 \% \mathrm{Zn}(\mathrm{II}): 13.38 \% \mathrm{Cd}(\mathrm{II})$ and $89.11 \%$ $\mathrm{Zn}(\mathrm{II}): 10.89 \% \mathrm{Cd}(\mathrm{II})$ respectively.

Using the concentration ranges as described for the binary mixtures, the ternary mixtures, $\mathrm{Zn}(\mathrm{II})+\mathrm{Cd}(\mathrm{II})+\mathrm{Ni}(\mathrm{II})$ and $\mathrm{Ni}(\mathrm{II})+\mathrm{Co}(\mathrm{II})+\mathrm{Cd}(\mathrm{II})$ were also designed along fixed ratio rays. Three uniform design concentration ratios (UDCR) and two equieffect concentration ratios (EECR-20 and EECR-50) were evaluated. The quaternary mixtures of the four metals ions $[\mathrm{Ni}(\mathrm{II})+\mathrm{Co}(\mathrm{II})+\mathrm{Zn}(\mathrm{II})+\mathrm{Cd}(\mathrm{II})]$ were also designed along fixed ratio rays. The specific ratios of metal ions in the 
ternary and quaternary mixtures are as shown in Table 1 . The mixtures were prepared as $10 \mathrm{mM}$ stock solutions by mixing requisite volumes of the individual metal ion solution to give a specific concentration ratio. Each mixture was treated as single metal ion solution.

\section{Acute toxicity assay}

The assay for dehydrogenase activity in the presence of metal ions was modified from Nweke et al. (2014). 2,3,5-triphenyltetrazolium chloride (TTC) was used as an artificial electron acceptor instead of 2-(p-Iodophenyl)3-(p-nitrophenyl)-5-phenyl tetrazolium chloride (INT) in a lower strength culture medium. The reaction mixture consisted of 2-ml final volumes of low-strength nutrient broth supplemented with varying concentrations of metal ions ( $\mathrm{pH}$ 7.2). Into each tube containing $0.5 \mathrm{ml}$ portion of X4strength nutrient broth, requisite volumes of distilled water and stock solutions of respective metal ion(s) were added. The final amount of nutrient broth in the reaction mixture was $0.2 \% \mathrm{w} / \mathrm{v}$. Thereafter, $0.1 \mathrm{ml}$ of $0.1 \%$ aqueous solution of TTC and $0.1 \mathrm{ml}$ of the standardized bacterial suspension were added into each tube to obtain varying concentrations of metal ions for the individual metals and the mixture ratios. Each concentration of the binary mixture and the individual metals were prepared in triplicates. Controls were prepared

Table 1: Experimental (observed) and predicted toxicity thresholds $\left(E C_{50}\right)$ of individual metals and their mixtures

\begin{tabular}{|c|c|c|c|}
\hline \multirow{3}{*}{ Metals and mixtures } & \multicolumn{3}{|c|}{$E C_{50}(\mathrm{mM})$} \\
\hline & \multirow{2}{*}{ Experimental } & \multicolumn{2}{|c|}{ Predicted } \\
\hline & & $\mathrm{CA}$ & IA \\
\hline $\mathrm{Ni}(\mathrm{II})$ & $0.356 \pm 0.028$ & - & - \\
\hline $\mathrm{Co}(\mathrm{II})$ & $0.123 \pm 0.006$ & - & - \\
\hline $\mathrm{Zn}(\mathrm{II})$ & $0.180 \pm 0.010$ & - & - \\
\hline $\mathrm{Cd}(\mathrm{II})$ & $0.022 \pm 0.001$ & - & - \\
\hline \multicolumn{4}{|l|}{$\mathrm{NI}(\mathrm{II})+\mathrm{Co}(\mathrm{II})$ mixtures } \\
\hline $\mathrm{Ni}(\mathrm{II}) 20 \%+\mathrm{Co}(\mathrm{II}) 80 \%$ & $0.305 \pm 0.033$ & $0.139 \pm 0.004$ & $0.144 \pm 0.004$ \\
\hline $\mathrm{Ni}(\mathrm{II}) 50 \%+\mathrm{Co}$ (II) $50 \%$ & $0.205 \pm 0.022^{*}$ & $0.179 \pm 0.006^{*}$ & $0.191 \pm 0.001 *$ \\
\hline $\mathrm{Ni}(\mathrm{II}) 80 \%+\mathrm{Co}$ (II) $20 \%$ & $0.273 \pm 0.020^{*}$ & $0.253 \pm 0.010^{*}$ & $0.283 \pm 0.002 *$ \\
\hline $\mathrm{Ni}(\mathrm{II}) 66.06 \%+\mathrm{Co}(\mathrm{II}) 33.94 \%$ (EECR 20 ) & $0.138 \pm 0.021$ & $0.212 \pm 0.008$ & $0.232 \pm 0.001$ \\
\hline $\mathrm{Ni}(\mathrm{II}) 74.32 \%+\mathrm{Co}$ (II) $25.68 \%$ (EECR 50 ) & $0.141 \pm 0.024$ & $0.239 \pm 0.015$ & $0.260 \pm 0.001$ \\
\hline \multicolumn{4}{|l|}{$\mathrm{Zn}(\mathrm{II})+\mathrm{Cd}(\mathrm{II})$ mixtures } \\
\hline $\mathrm{Zn}(\mathrm{II}) 71.43 \%+\mathrm{Cd}(\mathrm{II}) 28.57 \%$ & $0.056 \pm 0.008^{*}$ & $0.060 \pm 0.004^{*}$ & $0.062 \pm 0.001 *$ \\
\hline Zn(II) $90.91 \%+$ Cd(II) $9.09 \%$ & $0.117 \pm 0.017^{*}$ & $0.110 \pm 0.007 *$ & $0.117 \pm 0.001 *$ \\
\hline $\mathrm{Zn}$ (II) $97.56 \%+\mathrm{Cd}(\mathrm{II}) 2.44 \%$ & $0.078 \pm 0.018$ & $0.154 \pm 0.009$ & $0.165 \pm 0.004$ \\
\hline $\mathrm{Zn}$ (II) $86.62 \%+\mathrm{Cd}(\mathrm{II}) 13.38 \%$ (EECR-20) & $0.044 \pm 0.008$ & $0.093 \pm 0.006$ & $0.098 \pm 0.000$ \\
\hline Zn(II) $89.11 \%+$ Cd(II) $10.89 \%$ (EECR-50) & $0.051 \pm 0.011$ & $0.102 \pm 0.006$ & $0.108 \pm 0.001$ \\
\hline \multicolumn{4}{|l|}{$\mathrm{Zn}(\mathrm{II})+\mathrm{Cd}(\mathrm{II})+\mathrm{Ni}(\mathrm{II})$ Ternary Mixtures } \\
\hline $\mathrm{Zn}(\mathrm{II}) 68.49 \%+\mathrm{Cd}(\mathrm{II}) 4.11 \%+\mathrm{Ni}(\mathrm{II}) 27.40 \%$ & $0.068 \pm 0.007$ & $0.154 \pm 0.012$ & $0.169 \pm 0.004$ \\
\hline $\mathrm{Zn}$ (II) $36.585 \%+\mathrm{Cd}$ (II) $2.439 \%+\mathrm{Ni}(\mathrm{II}) 60.976 \%$ & $0.110 \pm 0.012$ & $0.207 \pm 0.014$ & $0.221 \pm 0.006$ \\
\hline $\mathrm{Zn}(\mathrm{II}) 43.48 \%+\mathrm{Cd}(\mathrm{II}) 13.04 \%+\mathrm{Ni}(\mathrm{II}) 43.48 \%$ & $0.040 \pm 0.005$ & $0.106 \pm 0.007$ & $0.112 \pm 0.002$ \\
\hline $\mathrm{Zn}$ (II) $33.70 \%+\mathrm{Cd}$ (II) $5.20 \%+\mathrm{Ni}(\mathrm{II}) 61.10 \%($ EECR-20) & $0.070 \pm 0.008$ & $0.169 \pm 0.012$ & $0.182 \pm 0.006$ \\
\hline $\mathrm{Zn}(\mathrm{II}) 32.30 \%+\mathrm{Cd}(\mathrm{II}) 3.90 \%+\mathrm{Ni}(\mathrm{II}) 63.80 \%(\mathrm{EECR}-50)$ & $0.055 \pm 0.007$ & $0.188 \pm 0.013$ & $0.202 \pm 0.007$ \\
\hline \multicolumn{4}{|l|}{$\mathrm{Ni}(\mathrm{II})+\mathrm{Co}(\mathrm{II})+\mathrm{Cd}(\mathrm{II})$ Ternary Mixtures } \\
\hline $\mathrm{Ni}(\mathrm{II}) 36.58 \%+\mathrm{Co}(\mathrm{II}) 60.58 \%+\mathrm{Cd}(\mathrm{II}) 2.44 \%$ & $0.225 \pm 0.019$ & $0.139 \pm 0.005$ & $0.160 \pm 0.001$ \\
\hline $\mathrm{Ni}(\mathrm{II}) 32.57 \%+\mathrm{Co}(\mathrm{II}) 65.93 \%+\mathrm{Cd}(\mathrm{II}) 1.10 \%$ & $0.401 \pm 0.026$ & $0.145 \pm 0.004$ & $0.161 \pm 0.002$ \\
\hline $\mathrm{Ni}(\mathrm{II}) 60.98 \%+\mathrm{Co}(\mathrm{II}) 36.58 \%+\mathrm{Cd}(\mathrm{II}) 2.44 \%$ & $0.222 \pm 0.018$ & $0.170 \pm 0.006$ & $0.203 \pm 0.005$ \\
\hline $\mathrm{Ni}(\mathrm{II}) 62.54 \%+\mathrm{Co}(\mathrm{II}) 32.13 \%+\mathrm{Cd}(\mathrm{II}) 5.33 \%$ (EECR-20) & $0.333 \pm 0.026$ & $0.146 \pm 0.007$ & $0.178 \pm 0.006$ \\
\hline $\mathrm{Ni}(\mathrm{II}) 71.08 \%+\mathrm{Co}$ (II) $24.55 \%+\mathrm{Cd}$ (II) $4.39 \%$ (EECR-50) & $0.235 \pm 0.019$ & $0.165 \pm 0.008$ & $0.201 \pm 0.007$ \\
\hline \multicolumn{4}{|l|}{$\mathrm{Ni}(\mathrm{II})+\mathrm{Co}(\mathrm{II})+\mathrm{Zn}(\mathrm{II})+\mathrm{Cd}(\mathrm{II})$ Quaternary Mixtures } \\
\hline $\mathrm{Ni}$ (II) $60.98 \%+\mathrm{Co}$ (II) $24.39 \%+\mathrm{Zn}$ (II) $12.19 \%+\mathrm{Cd}$ (II) $2.43 \%$ & $0.102 \pm 0.016$ & $0.183 \pm 0.012$ & $0.224 \pm 0.010$ \\
\hline $\mathrm{Ni}(\mathrm{II}) 32.258 \%+\mathrm{Co}(\mathrm{II}) 32.258 \%+\mathrm{Zn}$ (II) $32.258 \%+\mathrm{Cd}(\mathrm{II}) 3.226 \%$ & $0.068 \pm 0.017$ & $0.148 \pm 0.009$ & $0.182 \pm 0.009$ \\
\hline $\mathrm{Ni}(\mathrm{II}) 46.48 \%+\mathrm{Co}$ (II) $23.88 \%+\mathrm{Zn}$ (II) $25.67 \%+\mathrm{Cd}(\mathrm{II}) 3.97 \%(\mathrm{EECR}-20)$ & $0.095 \pm 0.012$ & $0.155 \pm 0.010$ & $0.192 \pm 0.010$ \\
\hline $\mathrm{Ni}(\mathrm{II}) 52.28 \%+\mathrm{Co}(\mathrm{II}) 18.06 \%+\mathrm{Zn}$ (II) $26.43 \%+\mathrm{Cd}(\mathrm{II}) 3.23 \%$ (EECR-50) & $0.147 \pm 0.022$ & $0.171 \pm 0.011$ & $0.209 \pm 0.011$ \\
\hline
\end{tabular}

${ }^{*} E C_{50}$ predicted from either CA or IA were not statistically different from observed $E C_{50}(\mathrm{p}>0.05)$ 
without the toxicants. Triplicate control tubes were prepared for each metal ion, giving a total of 12 controls. The cultures were incubated at room temperature $\left(28 \pm 2^{\circ} \mathrm{C}\right)$ for $24 \mathrm{~h}$. The extraction and quantification of TTC-formazan were done as described by Nweke et al. (2016).

\section{Data analysis}

The inhibition of dehydrogenase activity from each toxicity assessment was transformed relative to the mean control (SD $<5 \%$ ) to a 0 to $100 \%$ scale as shown in equation 1. The normalized responses were generated as mean and their standard deviations from triplicate determinations.

$$
\mathrm{R}=\left(1-\frac{T_{A}}{C_{A}}\right) \times 100
$$

Where $\mathrm{R}$ is the inhibition (\%) of dehydrogenase activity, $C_{A}$ is the absorbance of TPF extract in the control experiment and $T_{A}$ is absorbance of TPF extract in the test experiment with different concentrations of metal ion(s).

The dose-response data of the single substances as well as the mixtures were then plotted and fitted with 2-parameter logistic function (equation 2).

$$
\mathrm{R}=\frac{100}{1+\left(\frac{x}{E C_{50}}\right)^{b}}
$$

Where $x$ is the concentration of metal ion(s), $E C_{50}$ is the concentration of metal ion(s), that inhibited dehydrogenase activity by $50 \%$ and $b$ is the slope at $E C_{50}$.

\section{Prediction of mixture toxicities}

The toxicities of the mixtures can be determined from the toxicity of the individual component based on concentration addition (CA) model if the relative composition of each component is quantitatively known. The concept of concentration addition assumes that the components of the mixture acts similarly against the test organism. The CA model can be written as (Berenbaum, 1985):

$$
E C_{x(\text { mix })}=\left(\sum_{i=1}^{n} \frac{\pi_{i}}{E C_{x i}}\right)^{-1}
$$

Where $E C x_{\text {(mix) }}$ is the total concentration of the mixture that elicited $x \%$ effect, $E C_{x i}$ is the concentration of $i$ th component that gave $x$ effect when tested as an individual, $n$ is the number of components, $\pi_{i}$ is the proportion of $i$ th component in the mixture, such that the sum of $\pi_{i}=1$. Using equation 3 , the toxicities of the mixtures were predicted as described elsewhere (Altenburger et al., 2000; Backhaus et al., 2000). The total concentration of each mixture that elicited $1-99 \%$ effects were calculated in steps of $1 \%$. The resulting 99 concentration/effect pairs were plotted as a line chart giving a visualization of the predicted dose-response curve. First, the $E C_{x}$ for $1-99 \%$ was calculated for each component from the logistic dose-response model that fitted the individual doseresponse data. Secondly, the $E C_{x}$ values were substituted in equation 3 to obtain the $1-99 \% \mathrm{EC} x_{\text {(mix) }}$ values for each mixture. These calculations were done with Microsoft Excel 2003 and the data obtained were plotted using Sigmaplot 10.

The independent action (IA) or response addition model assumes that the components of a given mixture have different mode of action. The mathematical expression is as follows (Altenburger et al., 2000; Faust et al., 2003):

$$
E\left(c_{\text {mix }}\right)=1-\prod_{i=1}^{n}\left[1-E\left(c_{i}\right)\right]
$$

Where $E\left(c_{\text {mix }}\right)$ represents the total effect or response (scaled from 0 to 1) of an $n$-component mixture, $c_{i}$ is the concentration of the $i$ th component and $E\left(c_{i}\right)$ is the effect or response of the individual component. The dose-response relationships $F_{i}$ of the individual components were used to calculate their effects $\mathrm{E}\left(c_{i}\right)$ as shown below (Backhaus et al., 2000):

$$
E\left(c_{\text {mix }}\right)=1-\prod_{i=1}^{n}\left[1-E\left(c_{i}\right)\right]=1-\prod_{i=1}^{n}\left[1-F_{i}\left(c_{i}\right)\right]
$$

By expressing the concentrations of the individual components as fractions, $\pi_{i}$, of the total concentration, $c_{\text {mix }}$, the overall effect of any given mixture concentration can be calculated as:

$$
E\left(c_{\text {mix }}\right)=1-\prod_{i}^{n}\left[1-E\left(c_{i}\right)\right]=1-\prod_{1}^{n}\left[1-F\left(\pi_{i} \cdot c_{m i x}\right)\right]
$$

The total effect $E\left(c_{m i x}\right)$ of each mixture were calculated for $c_{\text {mix }}$ values ranging from $0.004-4 \mathrm{mM}$ and multiplied by 100 , as shown in equation 7 , to rescale the effect from 0 to $100 \%$.

$$
E\left(c_{\text {mix }}\right)=\left[1-\prod_{i=1}^{n}\left[1-F\left(\pi_{i} \cdot c_{\text {mix }}\right)\right]\right] \times 100
$$

To implement this, equation 2 was substituted into equation 7 for each metal ion as:

$$
\mathrm{R}=\frac{1}{1+\left(\frac{\pi_{i} x}{E C_{50}}\right)^{b}}
$$

Thus, the simplified expression of the independent action model is given as:

$$
E\left(c_{\text {mix }}\right)=\left[1-\prod_{i=1}^{n}\left[1-\frac{1}{1+\left(\frac{\pi_{i} x}{E C_{50 i}}\right)^{b_{i}}}\right] \times 100\right.
$$


Where $\pi_{i} x$ is the concentration of $i$ th component in the mixture. The values of $E C_{50 i}$ and $b_{i}$ as generated from equation 2 for individual metal ion were used.

The resulting concentration/effect pairs were plotted as a line chart giving a visualization of the dose-response curve predicted from the independent action model.

\section{The toxic index (TI)}

The Toxic Index (TI) of each mixture was calculated as sum of toxic units for all the components of the mixture (equation 10).

$$
\mathrm{TI}=\sum_{i=1}^{n} \frac{C_{i}}{E C_{50 i}}=\sum_{i=1}^{n} \frac{\pi_{i} E C_{50 \mathrm{mix}}}{E C_{50 i}}
$$

Where $C_{i}$ is the concentration of the $i$ th component in the mixture at the $E C_{50}$ of the mixture $\left(E C_{50 m i x}\right)$ and $E C_{50 i}$ is the concentration of the $i$ th component that elicited $50 \%$ decrease in dehydrogenase activity when tested as an individual, $n$ is the number of components in the mixture and $\pi_{i}$ is the proportion of $i$ th component in the mixture. TI $=1$ describes additivity, TI $>1$ describes antagonistic interaction and $\mathrm{TI}<1$ describes synergistic interaction (Boillot \& Perrodin, 2008).

\section{Model deviation ratios}

The model deviation ratios (MDR) were calculated as the ratio of the predicted $E C_{50}$ to the experimentally-derived $E C_{50}$. MDR greater than 1 indicated that the model underestimated toxicity, while a value of less than 1 indicated that the model overestimated toxicity. MDR values ranging from 0.5 to 2 ( 0.5 $\leq \mathrm{MDR} \leq 2)$ indicated that the mixture was most likely to be additive (Petersen \& Tollefsen, 2011; Li et al., 2014).

\section{Isobolographic analysis}

The estimated $E C_{50}$ were used in subsequent determination of isoboles and isobolographic analysis of the binary mixture toxicity as described by Nweke et al. (2014). The concentrations of each component at $E C_{50}\left(C_{i}\right)$ were calculated and used to compute the isoboles. The $C_{i}$ values $\left(C_{i A}\right.$ and $\left.C_{i B}\right)$ for the components can be calculated by multiplying the proportion of individual component in the mixture by the $E C_{50}$ of the mixture as in the numerator of equation 10. Triplicate isoboles were generated and plotted in an isobologram as described elsewhere (Boillot \& Perrodin, 2008; Nweke et al., 2014). The straight line joining the $\mathrm{EC}_{50}$ of component $\mathrm{A}$ on one axis and $\mathrm{EC}_{50}$ of component $\mathrm{B}$ on the other axis is the line of additivity representing the additive effect of the mixture. When an isobole plotted in the isobologram is below or above the additivity line, the interaction is taken to be synergistic or antagonistic respectively.

\section{RESULTS}

\section{Toxicity of individual metal ion}

The effects of the individual metal ion on the dehydrogenase activity of the $P$. fluorescens are shown in Figure 1. The responses of the organism to the toxicity of the metal ions was dose-dependent. The metal ions progressively inhibited the dehydrogenase activity as the concentrations were increased, giving percent inhibitions greater than $95 \%$ at $2 \mathrm{mM} \mathrm{Ni}$ (II) and $\mathrm{Zn}$ (ii), $1.5 \mathrm{mM} \mathrm{Co}$ (II) and $0.2 \mathrm{mM} \mathrm{Cd}$ (II). The $\mathrm{EC}_{50}$ values of the metals ranged from $0.022 \mathrm{mM}$ for $\mathrm{Cd}$ (II) to $0.356 \mathrm{mM}$ for $\mathrm{Ni}$ (II) (Table 1). The experimental data for all the metals were fitted with 2-parameter logistic model to obtain the predicted doseresponse curve. The shapes of the dose-response curves are rather similar, indicating the similarity of the molecular mechanisms of the actions of the metal ions. The Duncan test indicates that the $\mathrm{EC}_{50}$ of the metals were significantly different from each other and the order of toxicity is $\mathrm{Cd}(\mathrm{II})>\mathrm{Co}(\mathrm{II})>\mathrm{Zn}(\mathrm{II})>\mathrm{Ni}(\mathrm{II})$.

\section{Toxicity of mixtures}

The experimental dose-response relationships of the binary mixtures as well as the predictions made from CA and IA models are shown in Figures 2 and 3. The concentration addition and independent action concepts predicted similar toxicities for the binary mixtures, especially for $\mathrm{Zn}(\mathrm{II})$ and $\mathrm{Cd}(\mathrm{II})$ mixtures, and their dose-response curves were almost superimposed. The $\mathrm{EC}_{50}$ values predicted from the concepts for $\mathrm{Zn}(\mathrm{II})+\mathrm{Cd}(\mathrm{II})$ mixtures were not statistically different from each other. As seen from Figure 2, both CA and IA models predicted higher toxicity for $20 \% \mathrm{Ni}(\mathrm{II}): 80 \% \mathrm{Co}$ (II) mixture than suggested by the experimental data. As shown in Figure 2, both models predicted lower toxicities of equieffect mixtures (EECR-20 and EECR-50) of Ni(II) and Co(II) at low concentrations of the metal ions. Both models predicted accurately the toxicities of $50 \% \mathrm{Ni}(\mathrm{II})+50 \% \mathrm{Co}(\mathrm{II})$ and $80 \% \mathrm{Ni}(\mathrm{II})+20 \% \mathrm{Co}$ (II) mixtures.

In the case of $\mathrm{Zn}(\mathrm{II})$ and $\mathrm{Cd}(\mathrm{II})$ mixtures, the concepts of concentration addition and independent action predicted lower toxicities of EECR-20, EECR-50 and $97.56 \% \mathrm{Zn}(\mathrm{II})+$ $2.44 \% \mathrm{Cd}(\mathrm{II})$ mixtures than the observed toxicities (Figure 3 ). Toxicities similar to the experimentally derived values were predicted by both concepts for $90.91 \% \mathrm{Zn}(\mathrm{II})+9.09 \% \mathrm{Cd}(\mathrm{II})$ and $71.43 \% \mathrm{Zn}$ (II) $+28.57 \% \mathrm{Cd}(\mathrm{II})$ mixtures (Figure 3).

The $\mathrm{EC}_{50}$ of the binary mixtures as derived from logistic model regression of the experimental data and as predicted from concentration addition and independent action models are shown in Table 2. Statistical analysis indicated that there were no significant differences $(\mathrm{p}>0.05)$ between the $\mathrm{EC}_{50}$ values estimated from both models for all the $\mathrm{Zn}$ (II) $+\mathrm{Cd}$ (II) mixtures. Lack of significant difference between the $\mathrm{EC}_{50}$ values predicted by both models only occurred with $50 \% \mathrm{Ni}$ (II) $+50 \% \mathrm{Co}$ (II) and EECR 50 mixtures of $\mathrm{Ni}$ (II) and $\mathrm{Co}(\mathrm{II})$. The $\mathrm{EC}_{50}$ derived experimentally were not significantly different from the EC50 values predicted by both models for $80 \%$ $\mathrm{Ni}(\mathrm{II})+20 \% \mathrm{Co}(\mathrm{II})$ and $50 \% \mathrm{Ni}(\mathrm{II})+50 \% \mathrm{Co}(\mathrm{II})$ mixtures. Similarly, for the mixtures $71.43 \% \mathrm{Zn}(\mathrm{II})+28.57 \% \mathrm{Cd}$ (II) and $90.91 \% \mathrm{Zn}(\mathrm{II})+9.09 \% \mathrm{Cd}(\mathrm{II})$, the $\mathrm{EC}_{50}$ values predicted by both concepts were not statistically different from the values obtained experimentally. 

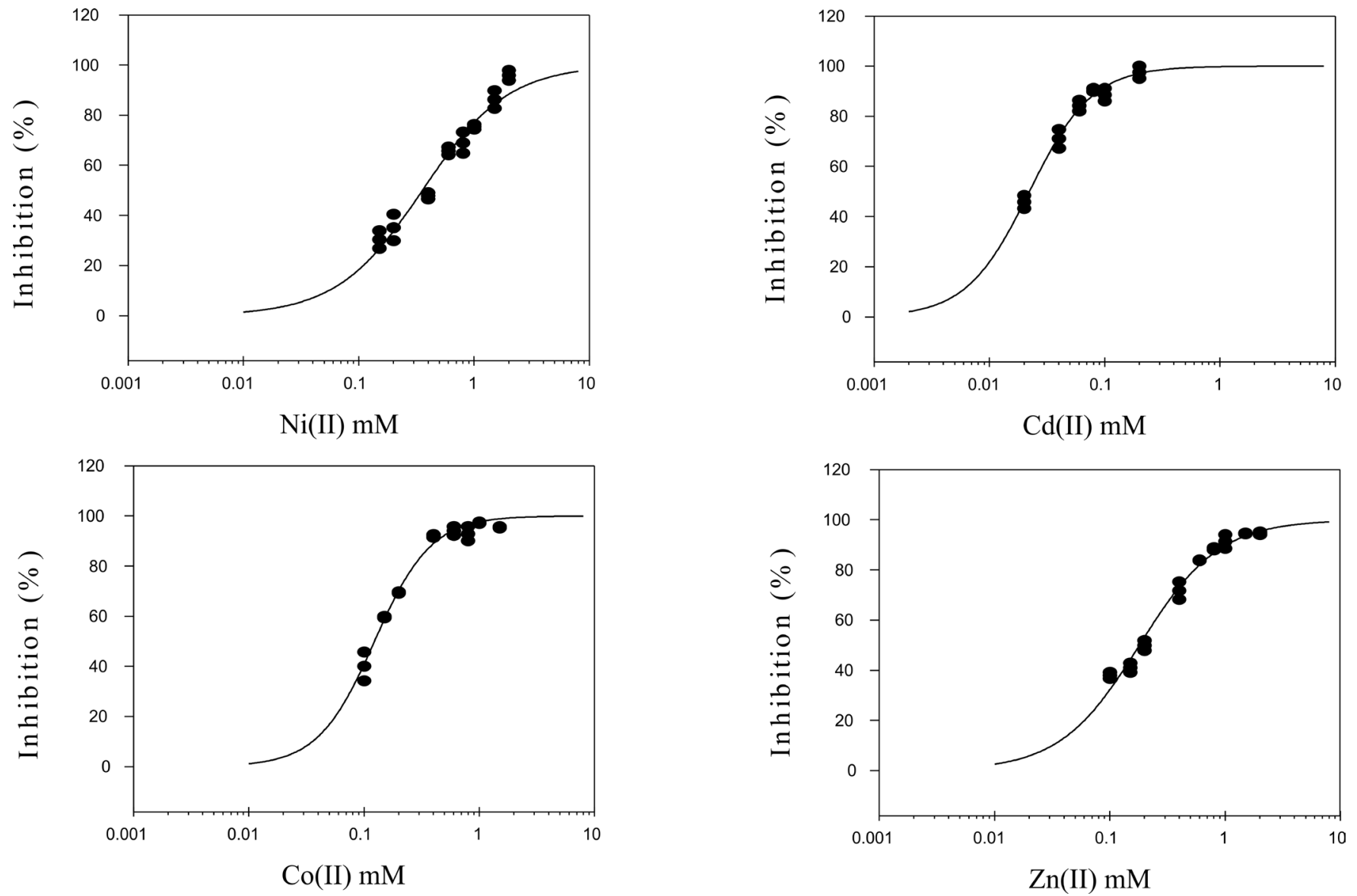

Figure 1: Inhibition of dehydrogenase activity in Pseudomonas fluorescens by the individual metal ions
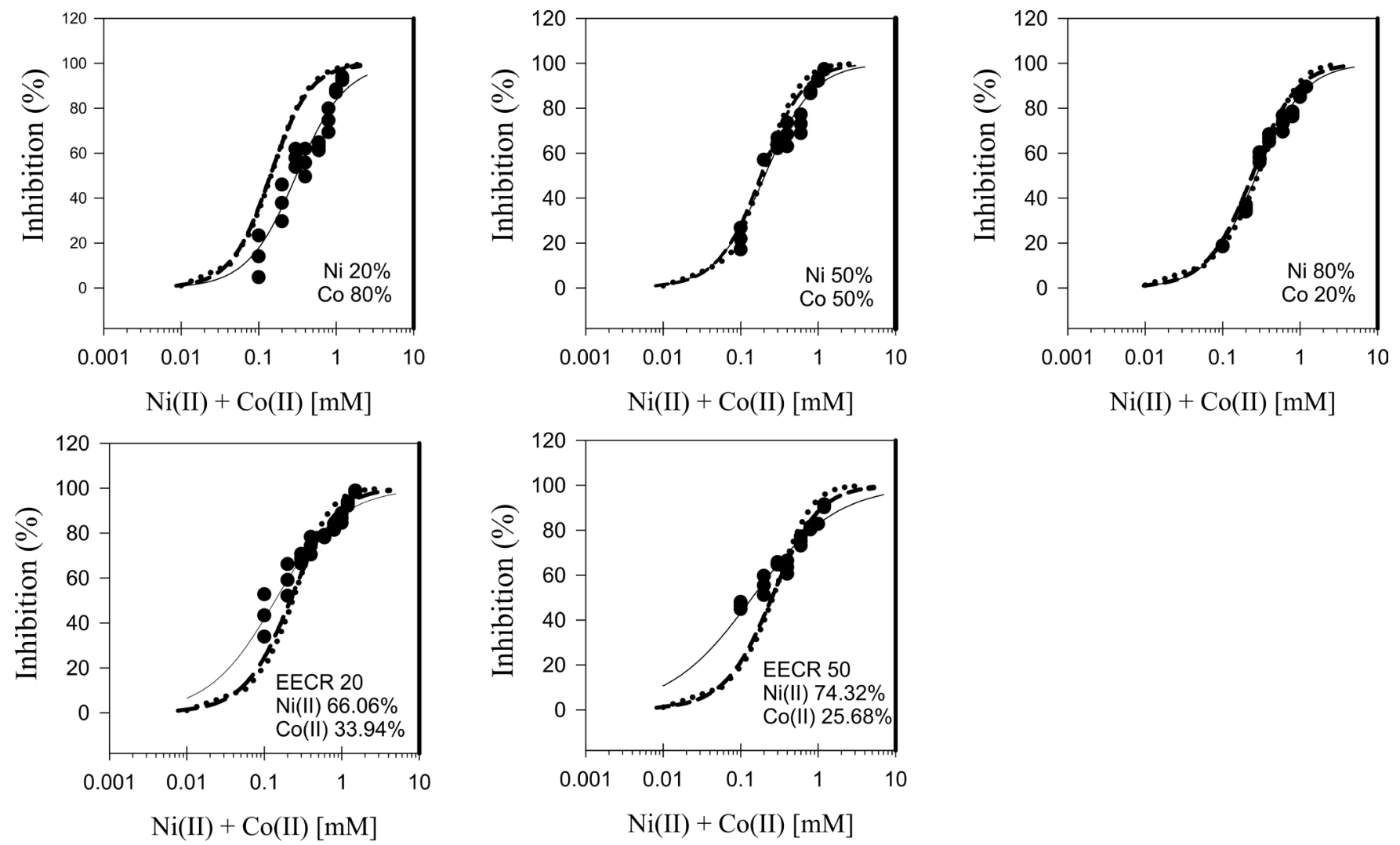

Figure 2: Experimental and predicted inhibitions of Pseudomonas fluorescens dehydrogenase activity by binary mixtures of nickel and cobalt ions. The data points represent experimental dose-response data. The solid lines represent toxicities obtained from fitting experimental data to logistic model (equation 2). Dashed lines represent toxicities predicted from the concentration addition model while dotted lines represent toxicities predicted from the independent action model 

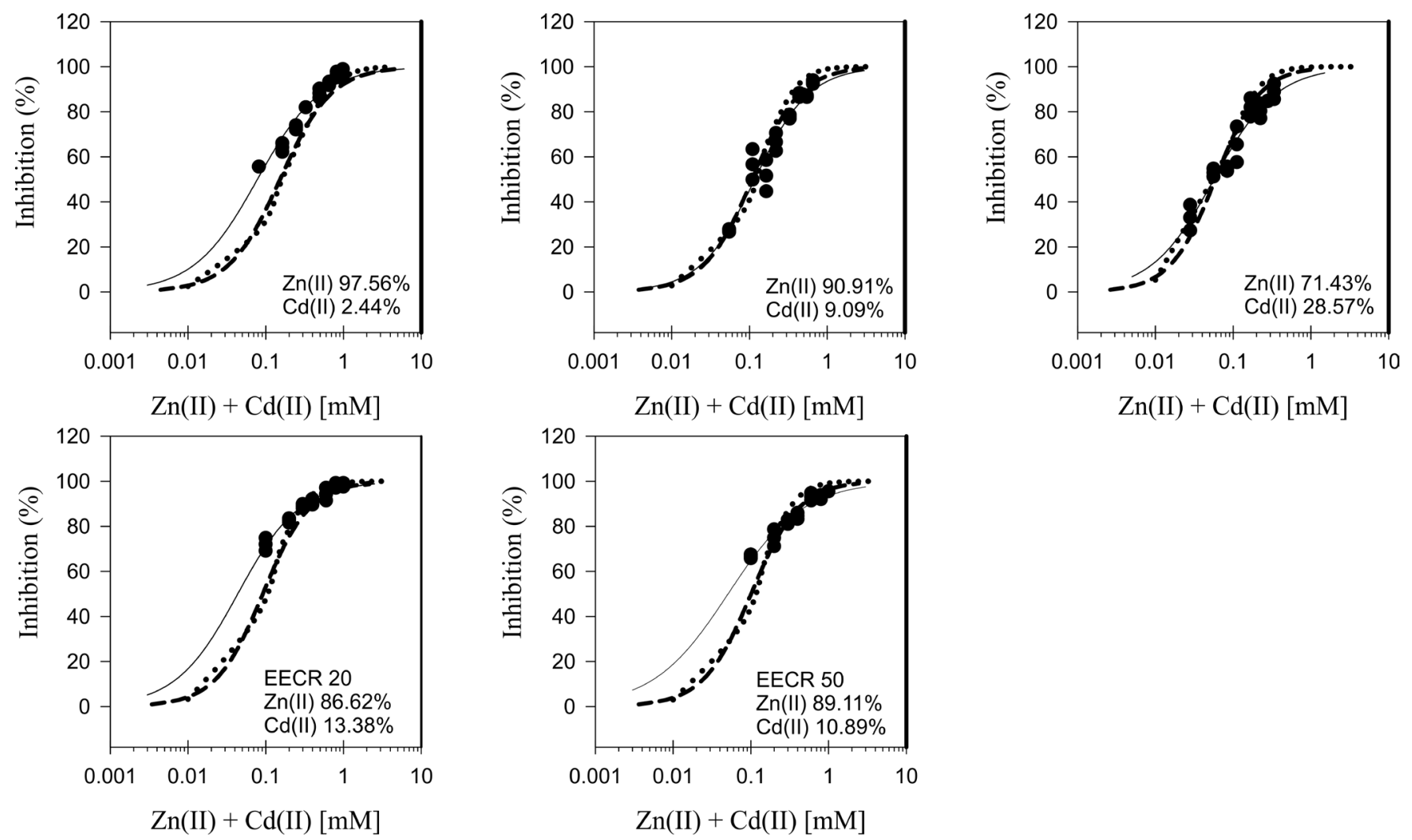

Figure 3: Observed and predicted inhibitions of Pseudomonas fluorescens dehydrogenase activity by binary mixtures of zinc and cadmium ions. The data points represent experimental dose-response data. The solid lines represent toxicities obtained from fitting experimental data to logistic model (equation 2). The Dashed lines represent toxicities predicted from the concentration addition model while the dotted lines represent toxicities predicted from independent action model.

The isobolographic analyses of the binary mixtures based on the $\mathrm{EC}_{50}$ values are shown in Figure 4. The isobologram indicated synergistic effect of the EECR-20 and EECR-50 equieffect mixtures, additive effect of $50 \% \mathrm{Ni}(\mathrm{II})+50 \%$ $\mathrm{Co}(\mathrm{II})$ and $80 \% \mathrm{Ni}(\mathrm{II})+20 \% \mathrm{Co}(\mathrm{II})$ and antagonistic effect of $20 \% \mathrm{Ni}(\mathrm{II})+80 \% \mathrm{Co}(\mathrm{II})$ for $\mathrm{Ni}(\mathrm{II})+\mathrm{Co}(\mathrm{II})$ mixtures. In addition, for the $\mathrm{Zn}(\mathrm{II})+\mathrm{Cd}$ (II) mixtures, the isobologram depicts synergistic effect of both equieffect mixtures and $97.56 \% \mathrm{Zn}(\mathrm{II})+2.44 \% \mathrm{Cd}(\mathrm{II})$ as well as additive effects of $71.43 \% \mathrm{Zn}(\mathrm{II})+28.57 \% \mathrm{Cd}(\mathrm{II})$ and $90.91 \% \mathrm{Zn}(\mathrm{II}): 9.09 \%$ $\mathrm{Cd}(\mathrm{II})$ mixtures. These observations were corroborated by the toxic index values as shown in Table 2 .

The dose-response relationships for ternary and quaternary mixtures of metal ions are shown in Figures 5 - 7. The doseresponse patterns are similar to those of binary mixtures and were describable with the 2-parameter logistic model. The $\mathrm{EC}_{50}$ of the mixtures are shown in Table 1 . The $\mathrm{EC}_{50}$ of the $\mathrm{Zn}(\mathrm{II})+\mathrm{Cd}(\mathrm{II})+\mathrm{Ni}(\mathrm{II})$ mixtures ranged from $0.035 \mathrm{mM}$ to $0.122 \mathrm{mM}$ and seem to be dependent on the relative amount of $\mathrm{Cd}(\mathrm{II})$ in the mixture. Similar observation was made for $\mathrm{Ni}(\mathrm{II})$ $+\mathrm{Co}(\mathrm{II})+\mathrm{Cd}(\mathrm{II})$ mixtures with $\mathrm{EC}_{50}$ ranging from $0.204 \mathrm{mM}$ to $0.427 \mathrm{mM}$. The $\mathrm{EC}_{50}$ of the quaternary mixtures ranged from $0.051 \mathrm{mM}$ to $0.169 \mathrm{mM}$. The toxicities of the ternary and quaternary mixtures as predicted from CA and IA models are shown in Table 1. Generally, CA and IA models predicted lower toxicities of $\mathrm{Zn}(\mathrm{II})+\mathrm{Cd}(\mathrm{II})+\mathrm{Ni}$ (II) mixtures than the experiment would suggest. However, the reverse was the case with $\mathrm{Ni}$ (II) $+\mathrm{Co}(\mathrm{II})+\mathrm{Cd}(\mathrm{II})$ mixtures where the models predicted higher toxicities. The $\mathrm{EC}_{50}$ predicted by $\mathrm{CA}$ and IA models in all the $\mathrm{Zn}(\mathrm{II})+\mathrm{Cd}(\mathrm{II})+\mathrm{Ni}(\mathrm{II})$ mixtures were not significantly different from each other. As shown in Figure 7, CA and IA models predicted lower toxicities of the quaternary mixtures than were experimentally observed. However, the IA model predicted higher toxicities than CA model in all the quaternary mixtures.

The toxic indices and the effect of the mixtures on dehydrogenase activities are shown in Table 2. Generally, the ternary mixtures of $\mathrm{Zn}(\mathrm{II}), \mathrm{Cd}(\mathrm{II})$ and $\mathrm{Ni}(\mathrm{II})$ are synergistic while the ternary mixture of $\mathrm{Ni}(\mathrm{II}), \mathrm{Co}$ (II) and $\mathrm{Cd}(\mathrm{II})$ are antagonistic. The quaternary mixtures are synergistic except the EECR-50 mixture.

The relationship between the observed and predicted $\mathrm{EC}_{50}$ of the metal ion mixtures are shown in Figure 8. There were generally no good correlation between the observed $\mathrm{EC}_{50}$ and the $\mathrm{EC}_{50}$ predicted from either $\mathrm{CA}$ or IA model. However, there was fairly good correlation between observed and predicted $\mathrm{EC}_{50}$ for $\mathrm{Zn}(\mathrm{II})+\mathrm{Cd}(\mathrm{II})$ $+\mathrm{Ni}(\mathrm{II})$ ternary mixtures $\left(\mathrm{R}^{2}=0.632(\mathrm{CA}) ; \mathrm{R}^{2}=0.509\right.$ (IA)) Generally, observed $\mathrm{EC}_{50}$ decreased with increase in predicted $\mathrm{EC}_{50}$ for the binary mixtures of $\mathrm{Ni}(\mathrm{II})+\mathrm{Co}(\mathrm{II})$ 

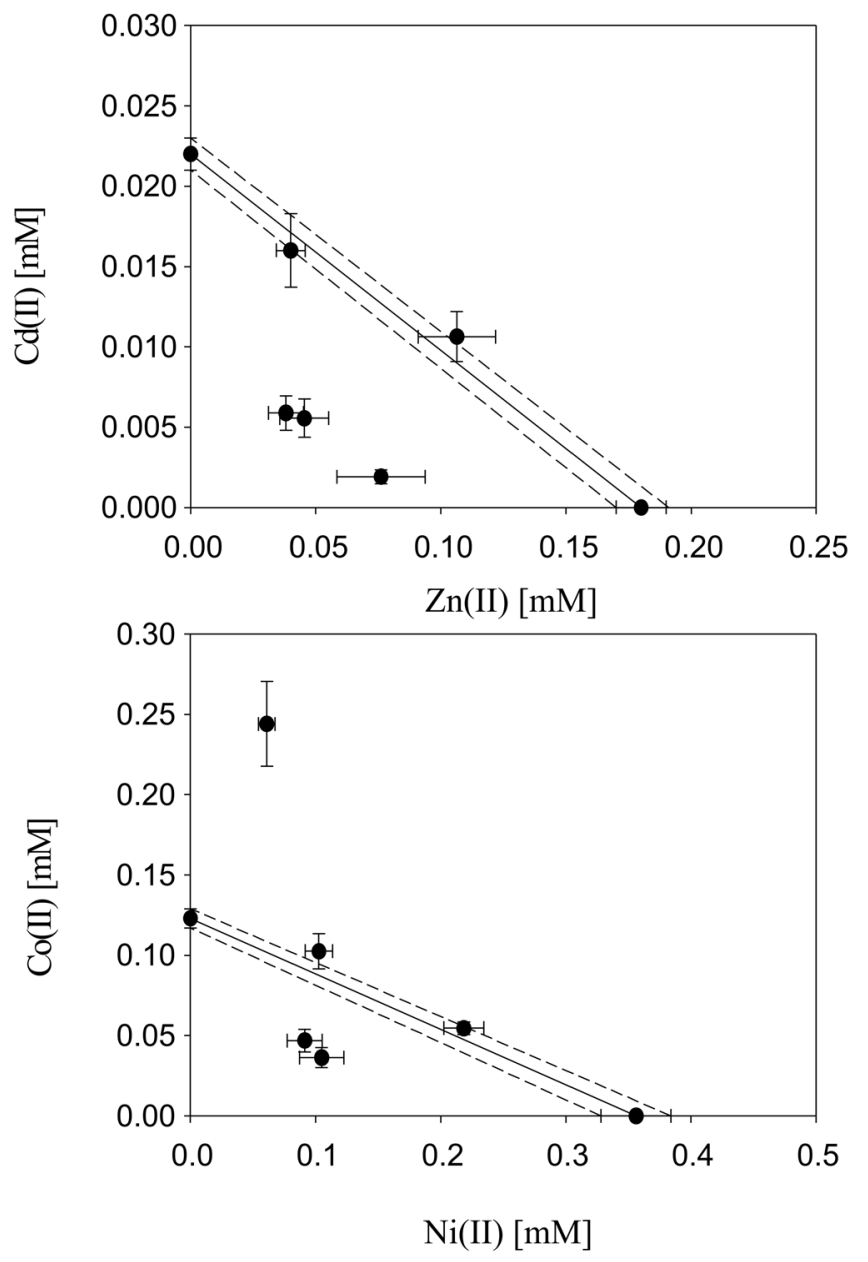

Figure 4. The $E C_{50}$ isobole representations for metal ions as individual and mixtures tested against dehydrogenase activity of Pseudomonas fluorescens. The bars represent the standard deviations of the $95 \%$ confidence interval of the values. The solid and dotted lines represents additivity line and its $95 \%$ confidence belt

and ternary misture of $\mathrm{Ni}(\mathrm{II})+\mathrm{Co}(\mathrm{II})+\mathrm{Cd}(\mathrm{II})$. Conversely, the observed $\mathrm{EC}_{50}$ generally increased with increase in the predicted $\mathrm{EC}_{50}$ for $\mathrm{Zn}(\mathrm{II})+\mathrm{Cd}(\mathrm{II}), \mathrm{Zn}(\mathrm{II})+\mathrm{Cd}(\mathrm{II})+\mathrm{Ni}(\mathrm{II})$ and $\mathrm{Ni}(\mathrm{II})+\mathrm{Co}(\mathrm{II})+\mathrm{Zn}(\mathrm{II})+\mathrm{Cd}(\mathrm{II})$ mixtures.

\section{DISCUSSION}

Although $\mathrm{Zn}, \mathrm{Ni}$ and $\mathrm{Co}$ are trace elements, they are toxic to microorganisms at elevated concentrations. Heavy metal inhibition of dehydrogenase enzymes have been reported by Nweke and co-workers for pure cultures of bacteria and microbial community of soil and river water (Nweke et al., 2006; 2007a,b; Orji et al., 2008; Nweke \& Orji, 2009; Nweke \& Okpokwasili, 2012). Cadmium has no physiological function and strongly inhibit microbial metabolism even at low concentrations.

A $50 \%$ effective concentration $\left(\mathrm{EC}_{50}\right)$ of zinc against sediment communities and natural microbial community in compost was reported as $0.92 \mathrm{mM}$ and $0.05 \mathrm{mM}$ respectively using acetate incorporation (Barnhart \& Vestal, 1983). Minimum inhibitory concentration (MIC) of $1 \mathrm{mM} \mathrm{Zn}$ (II) was reported by Nies (1999) for Escherichia coli growing in TRIS-buffered mineral salt medium supplemented with yeast extract and sodium gluconate. The MIC is equivalent to the concentration of zinc ion that would inhibit dehydrogenase activity by $100 \%$ in this study. We estimated the $\mathrm{IC}_{100}$ at $1.483 \mathrm{mM} \mathrm{Zn(II)} \mathrm{in} \mathrm{this} \mathrm{study.} \mathrm{Like} \mathrm{zinc,} \mathrm{nickel}$ and cadmium ions were inhibitory to microbial activities at high concentrations. Codina et al. (1994) reported the $\mathrm{EC}_{50}$ of $763 \mathrm{mg} / \mathrm{l} \mathrm{Ni}(\mathrm{II})(\approx 13 \mathrm{mM})$ and $1301.2 \mathrm{mg} / \mathrm{l} \mathrm{Ni}(\mathrm{II})$ $(\approx 22.17 \mathrm{mM})$ for $P$. fluorescens growing in buffer and wastewater respectively. Cobet et al. (1970) reported total inhibition (100\%) of Arthrobacter marinus growth at 0.5 $\mathrm{mM} \mathrm{Ni(II).} \mathrm{Chen} \mathrm{et} \mathrm{al.} \mathrm{(2005)} \mathrm{estimated} \mathrm{EC}_{50}$ of $\mathrm{Co}$ (II) at $150 \mathrm{mg} / 1(\approx 2.55 \mathrm{mM})$ for Pseudomonas aeruginosa growing in a batch system. According to Nweke and Okpokwasili (2012), Co(II) inhibited 50\% of dehydrogenase activity in Pseudomonas species from petroleum refinery wastewater at $\mathrm{Co}$ (II) concentrations ranging from $0.065 \mathrm{mM}$ to $0.347 \mathrm{mM}$. Cadmium ion is known to be more toxic than zinc, cobalt and nickel ions. Median inhibitory concentrations $\left(\mathrm{IC}_{50} \mathrm{~s}\right)$ ranging from $0.237 \mathrm{mM}$ to $0.275 \mathrm{mM} \mathrm{Cd}$ (II) was reported by Nweke et al. (2007b) for the inhibition of dehydrogenase activity in

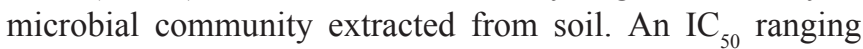
from $0.199 \mathrm{mM}$ to $0.239 \mathrm{mM} \mathrm{Cd}(\mathrm{II})$ against bioluminescence in photobacterium Q67 was reported by Ge et al. (2014). $\mathrm{IC}_{50}$ ranging from $0.026 \mathrm{mM}$ to $0.340 \mathrm{mM} \mathrm{Cd(II)} \mathrm{was} \mathrm{reported} \mathrm{for}$ Pseudomonas species by Nweke and Okpokwasili (2012). The order of toxicity in the present study is $\mathrm{Cd}(\mathrm{II})>\mathrm{Zn}$ (II) $>\mathrm{Co}(\mathrm{II})>\mathrm{Ni}(\mathrm{II})$. This order seemingly agreed with other reports in literature. $\mathrm{Cd}(\mathrm{II})$ is a non essential element and is generally more toxic than the essential elements. Co(II) has been found to be more toxic than Ni(II) to Pseudomonas species (Chandy, 1999). It is important to note that in this study, there was no stimulation of dehydrogenase activity even at the lowest concentration $(0.1 \mathrm{mM})$ of the tested metal ions. Stimulatory effects of metal ions have been reported for many microbial processes including dehydrogenase activity (Nweke et al., 2006; 2007a,b; Orji et al., 2008; Nweke \& Orji, 2009), growth (Visca et al., 1992; Osman et al., 2004; Rai \& Raizada, 1986; Gikas 2007) and bioluminescence (Christofi et al., 2002; Rodea-Palomares et al., 2009; Fulladosa et al., 2007). The absence of stimulatory effect in the present study may be attributed to the sensitivity of $P$. fluorescens to the metal ions or the fact that low concentration of nutrient broth was used which must have increased the bioavailability of the metal ions by reducing the tendency of the ions to bind to organic components of the medium.

Information on the effects of metal mixtures on microbial dehydrogenase activity is scarce. Toxicity of metal mixtures using other microbial responses has been reported by many researchers. However, little reports have been published on the combined effects of $\mathrm{Ni}(\mathrm{II})+\mathrm{Co}$ (II), $\mathrm{Zn}$ (II) $+\mathrm{Cd}$ (II), $\mathrm{Ni}(\mathrm{II})+\mathrm{Co}(\mathrm{II})+\mathrm{Cd}(\mathrm{II}), \mathrm{Zn}(\mathrm{II})+\mathrm{Cd}(\mathrm{II})+\mathrm{Ni}(\mathrm{II})$ and $\mathrm{Ni}(\mathrm{II})$ $+\mathrm{Co}(\mathrm{II})+\mathrm{Zn}(\mathrm{II})+\mathrm{Cd}(\mathrm{II})$ mixtures on microorganisms. Using isobolographic representation, Gikas (2007) reported synergistic toxicity of binary mixtures of $\mathrm{Ni}(\mathrm{II})$ and $\mathrm{Co}(\mathrm{II})$ 
Table 2: Toxic index and effect of binary mixtures of metal ions

\begin{tabular}{|c|c|c|c|}
\hline Metal mixtures & $\begin{array}{l}\text { Toxic Index } \\
\text { (TI) }\end{array}$ & MDR* & Effect \\
\hline \multicolumn{4}{|l|}{$\mathrm{NI}(\mathrm{II})+\mathrm{Co}(\mathrm{II})$ Binary Mixtures } \\
\hline $\mathrm{Ni}(\mathrm{II}) 20 \%+\mathrm{Co}$ (II) $80 \%$ & $2.153 \pm 0.127$ & $0.458 \pm 0.037$ & Antagonistic \\
\hline $\mathrm{Ni}(\mathrm{II}) 50 \%+\mathrm{Co}(\mathrm{II}) 50 \%$ & $1.119 \pm 0.057$ & $0.878 \pm 0.065$ & Additive \\
\hline $\mathrm{Ni}(\mathrm{II}) 80 \%+\mathrm{Co}$ (II) $20 \%$ & $1.057 \pm 0.008$ & $0.928 \pm 0.031$ & Additive \\
\hline $\mathrm{Ni}$ (II) $66.06 \%+\mathrm{Co}$ (II) $33.94 \%$ (EECR-20) & $0.635 \pm 0.058$ & $1.554 \pm 0.181$ & Synergistic \\
\hline $\mathrm{Ni}(\mathrm{II}) 74.32 \%+\mathrm{Co}(\mathrm{II}) 25.68 \%$ (EECR-50) & $0.586 \pm 0.063$ & $1.716 \pm 0.188$ & Synergistic \\
\hline \multicolumn{4}{|l|}{ Zn(II) + Cd(II) Binary Mixtures } \\
\hline $\mathrm{Zn}(\mathrm{II}) 71.43 \%+\mathrm{Cd}(\mathrm{II}) 28.57 \%$ & $0.940 \pm 0.081$ & $1.079 \pm 0.084$ & Additive \\
\hline $\mathrm{Zn}(\mathrm{II}) 90.91 \%+\mathrm{Cd}(\mathrm{II}) 9.09 \%$ & $1.062 \pm 0.089$ & $0.948 \pm 0.079$ & Addiitive \\
\hline $\mathrm{Zn}(\mathrm{II}) 97.56 \%+\mathrm{Cd}(\mathrm{II}) 2.44 \%$ & $0.474 \pm 0.052$ & $2.030 \pm 0.363$ & Synergistic \\
\hline $\mathrm{Zn}(\mathrm{II}) 86.62 \%+\mathrm{Cd}(\mathrm{II}) 13.38 \%($ EECR-20) & $0.469 \pm 0.052$ & $2.145+0.258$ & Synergistic \\
\hline $\mathrm{Zn}$ (II) $89.11 \%+\mathrm{Cd}(\mathrm{II}) 10.89 \%$ (EECR-50) & $0.498 \pm 0.078$ & $2.047 \pm 0.372$ & Synergistic \\
\hline \multicolumn{4}{|l|}{$\mathrm{Zn}(\mathrm{II})+\mathrm{Cd}(\mathrm{II})+\mathrm{Ni}(\mathrm{II})$ Ternary Mixtures } \\
\hline $\mathrm{Zn}(\mathrm{II}) 68.49 \%+\mathrm{Cd}(\mathrm{II}) 4.11 \%+\mathrm{Ni}(\mathrm{II}) 27.40 \%$ & $0.558 \pm 0.022$ & $2.269 \pm 0.057$ & Synergistic \\
\hline $\mathrm{Zn}(\mathrm{II}) 36.585 \%+\mathrm{Cd}(\mathrm{II}) 2.439 \%+\mathrm{Ni}(\mathrm{II}) 60.976 \%$ & $0.635 \pm 0.031$ & $1.888 \pm 0.079$ & Synergistic \\
\hline $\mathrm{Zn}$ (II) $43.48 \%+\mathrm{Cd}(\mathrm{II}) 13.04 \%+\mathrm{Ni}(\mathrm{II}) 43.48 \%$ & $0.423 \pm 0.027$ & $2.663 \pm 0.159$ & Synergistic \\
\hline $\mathrm{Zn}(\mathrm{II}) 33.70 \%+\mathrm{Cd}(\mathrm{II}) 5.20 \%+\mathrm{Ni}(\mathrm{II}) 61.10 \%$ (EECR-20) & $0.472 \pm 0.022$ & $2.422 \pm 0.106$ & Synergistic \\
\hline $\mathrm{Zn}$ (II) $32.30 \%+\mathrm{Cd}(\mathrm{II}) 3.90 \%+\mathrm{Ni}(\mathrm{II}) 63.80 \%$ (EECR-50) & $0.340 \pm 0.022$ & $3.435 \pm 0.202$ & Synergistic \\
\hline \multicolumn{4}{|l|}{$\mathrm{Ni}(\mathrm{II})+\mathrm{Co}(\mathrm{II})+\mathrm{Cd}(\mathrm{II})$ Ternary Mixtures } \\
\hline $\mathrm{Ni}$ (II) $36.58 \%+\mathrm{Co}$ (II) $60.58 \%+\mathrm{Cd}$ (II) $2.44 \%$ & $1.237 \pm 0.026$ & $0.619 \pm 0.030$ & Antagonistic \\
\hline $\mathrm{Ni}$ (II) $32.57 \%+\mathrm{Co}$ (II) $65.93 \%+\mathrm{Cd}$ (II) $1.10 \%$ & $2.033 \pm 0.007$ & $0.362 \pm 0.014$ & Antagonistic \\
\hline $\mathrm{Ni}$ (II) $60.98 \%+\mathrm{Co}$ (II) $36.58 \%+\mathrm{Cd}$ (II) $2.44 \%$ & $1.071 \pm 0.014$ & $0.768 \pm 0.035$ & Antagonistic \\
\hline $\mathrm{Ni}$ (II) $62.54 \%+\mathrm{Co}$ (II) $32.13 \%+\mathrm{Cd}(\mathrm{II}) 5.33 \%$ (EECR-20) & $1.974 \pm 0.020$ & $0.439 \pm 0.013$ & Antagonistic \\
\hline $\mathrm{Ni}$ (II) $71.08 \%+\mathrm{Co}$ (II) $24.55 \%+\mathrm{Cd}$ (II) $4.39 \%$ (EECR-50) & $1.250 \pm 0.016$ & $0.703 \pm 0.023$ & Antagonistic \\
\hline \multicolumn{4}{|l|}{$\mathrm{Ni}(\mathrm{II})+\mathrm{Co}(\mathrm{II})+\mathrm{Zn}(\mathrm{II})+\mathrm{Cd}(\mathrm{II})$ Quaternary Mixtures } \\
\hline $\mathrm{Ni}$ (II) $60.98 \%+\mathrm{Co}$ (II) $24.39 \%+\mathrm{Zn}$ (II) $12.19 \%+\mathrm{Cd}$ (II) $2.43 \%$ & $0.525 \pm 0.046$ & $1.812 \pm 0.169$ & Synergistic \\
\hline $\mathrm{Ni}$ (II) $32.258 \%+\mathrm{Co}$ (II) $32.258 \%+\mathrm{Zn}$ (II) $32.258 \%+\mathrm{Cd}$ (II) $3.226 \%$ & $0.517 \pm 0.047$ & $2.250 \pm 0.444$ & Synergistic \\
\hline $\mathrm{Ni}$ (II) $46.48 \%+\mathrm{Co}$ (II) $23.88 \%+\mathrm{Zn}$ (II) $25.67 \%+\mathrm{Cd}$ (II) $3.97 \%$ (EECR-20) & $0.618 \pm 0.037$ & $1.640 \pm 0.103$ & Synergistic \\
\hline $\mathrm{Ni}$ (II) $52.28 \%+\mathrm{Co}$ (II) $18.06 \%+\mathrm{Zn}$ (II) $26.43 \%+\mathrm{Cd}$ (II) $3.23 \%$ (EECR-50) & $0.887 \pm 0.076$ & $1.173 \pm 0.102$ & Additive \\
\hline
\end{tabular}

*MDR values are based CA predictions

against growth of activated sludge microbial community. However, in the same study, $\mathrm{Ni}(\mathrm{II})$ and $\mathrm{Co}(\mathrm{II})$ mixture was antagonistic at the zone of decreasing stimulation. This observation indicated that the overall effect of metal ion mixture may vary with the threshold under consideration. Similar observation was made in the present study where the CA and IA models underestimated toxicity of a specific mixture ratio at low doses and overestimated toxicity at high doses. The joint effect of $\mathrm{Ni}(\mathrm{II})$ and $\mathrm{Co}$ (II) on the growth of Klebsiella pneumoniae was characterized as additive (Ainswort et al., 1980). Synergistic interaction of $\mathrm{Ni}(\mathrm{II})$ and $\mathrm{Co}(\mathrm{II})$ against Escherichia coli and Alcaligenes eutrophus have also been reported (Barabasz et al., 1990). Using bioluminescent Vibrio fischeri, Fulladosa et al. (2005) reported antagonistic effect of equitoxic mixture of $\mathrm{Zn}$ (II) and $\mathrm{Cd}(\mathrm{II})$. Antagonistic effect of $\mathrm{Zn}(\mathrm{II})$ and $\mathrm{Cd}(\mathrm{II})$ was reported by Xu et al. (2011) using sea urchin embryo-larval assay. The toxicity of $\mathrm{Zn}(\mathrm{II})+\mathrm{Cd}(\mathrm{II})$ combinations was reported to be synergistic to a bioluminescent construct, Escherichia coli HB101 pUCD607. On the contrary, Chu and co-workers reported that $\mathrm{Zn}$ (II) could neutralize the toxicity of many metals (Chu et al., 2005; Chu \& Chow, 2002).

In the present study, isobolographic analysis and toxic index were used to characterize the joint effect of $\mathrm{Ni}(\mathrm{II})+$ $\mathrm{Co}$ (II) and $\mathrm{Zn}(\mathrm{II})+\mathrm{Cd}$ (II) binary mixture of. Both approaches indicated synergistic, antagonistic and additive effects for different ratios of the mixtures. These ratio-dependent effects have been reported for binary mixtures of heavy metal ions against Vibrio fischeri and Lemna minor (Ince et al., 1999). The CA and IA models were used to predict the joint action of the binary mixtures. Both model made good predictions for $50 \%$ $\mathrm{Ni}(\mathrm{II})+50 \% \mathrm{Co}(\mathrm{II}), 80 \% \mathrm{Ni}(\mathrm{II})+20 \% \mathrm{Co}$ (II), $71.43 \% \mathrm{Zn}$ (II) $+28.57 \% \mathrm{Cd}(\mathrm{II})$ and $90.91 \% \mathrm{Zn}(\mathrm{II})+9.09 \% \mathrm{Cd}(\mathrm{II})$ mixtures . However, in other cases, the model either overestimated or underestimated the joint toxicity of the metal mixture. This indicated the possibility of antagonistic and synergistic effects 

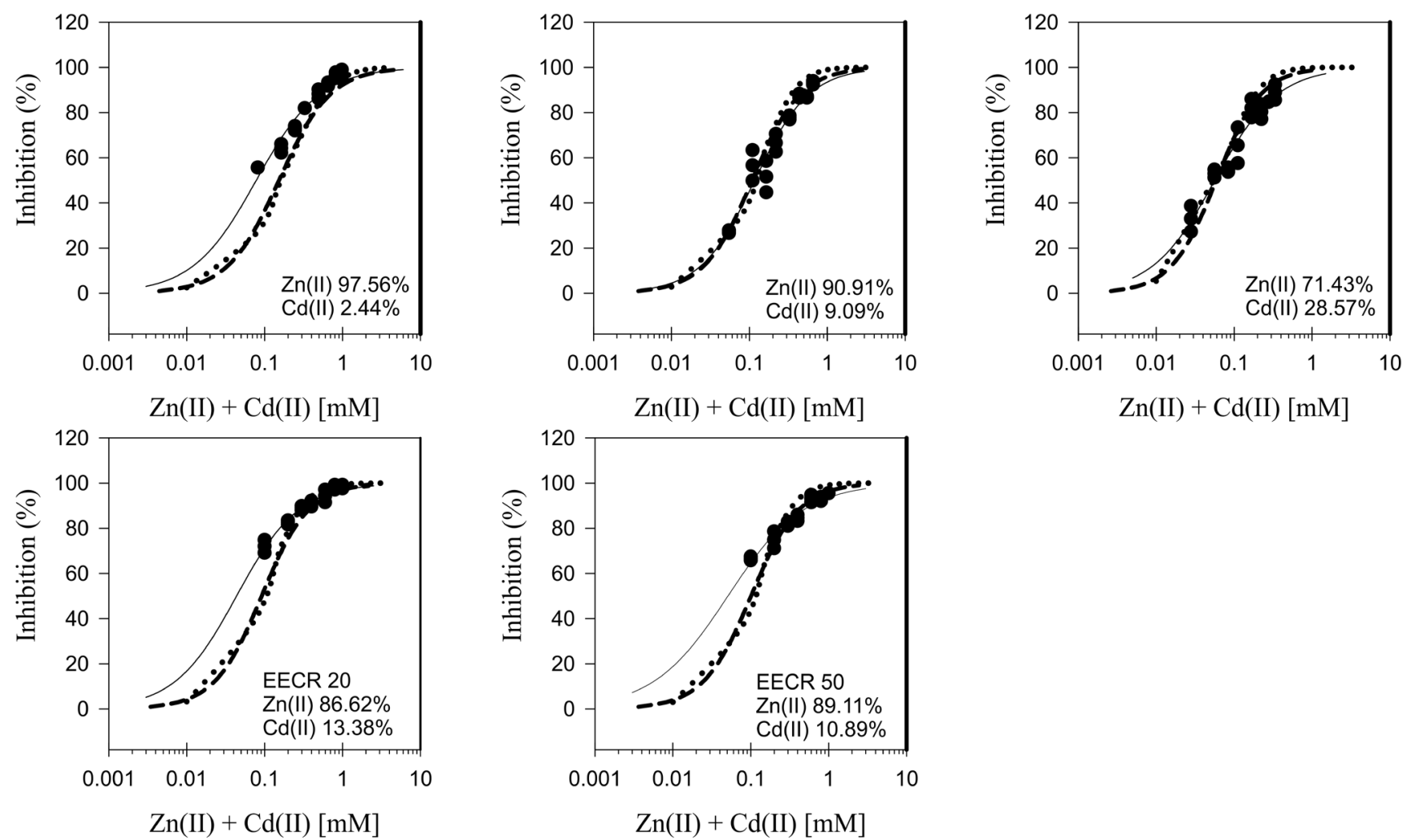

Figure 5: Observed and predicted inhibitions of Pseudomonas fluorescens dehydrogenase activity by ternary mixtures of zinc, cadmium and nickel ions. The data points represent experimental dose-response data. Solid lines represent toxicities obtained from fitting experimental data to logistic model (equation 2). The dashed lines represent toxicities predicted from the concentration addition model and the dotted lines represent toxicities predicted from the independent action model.
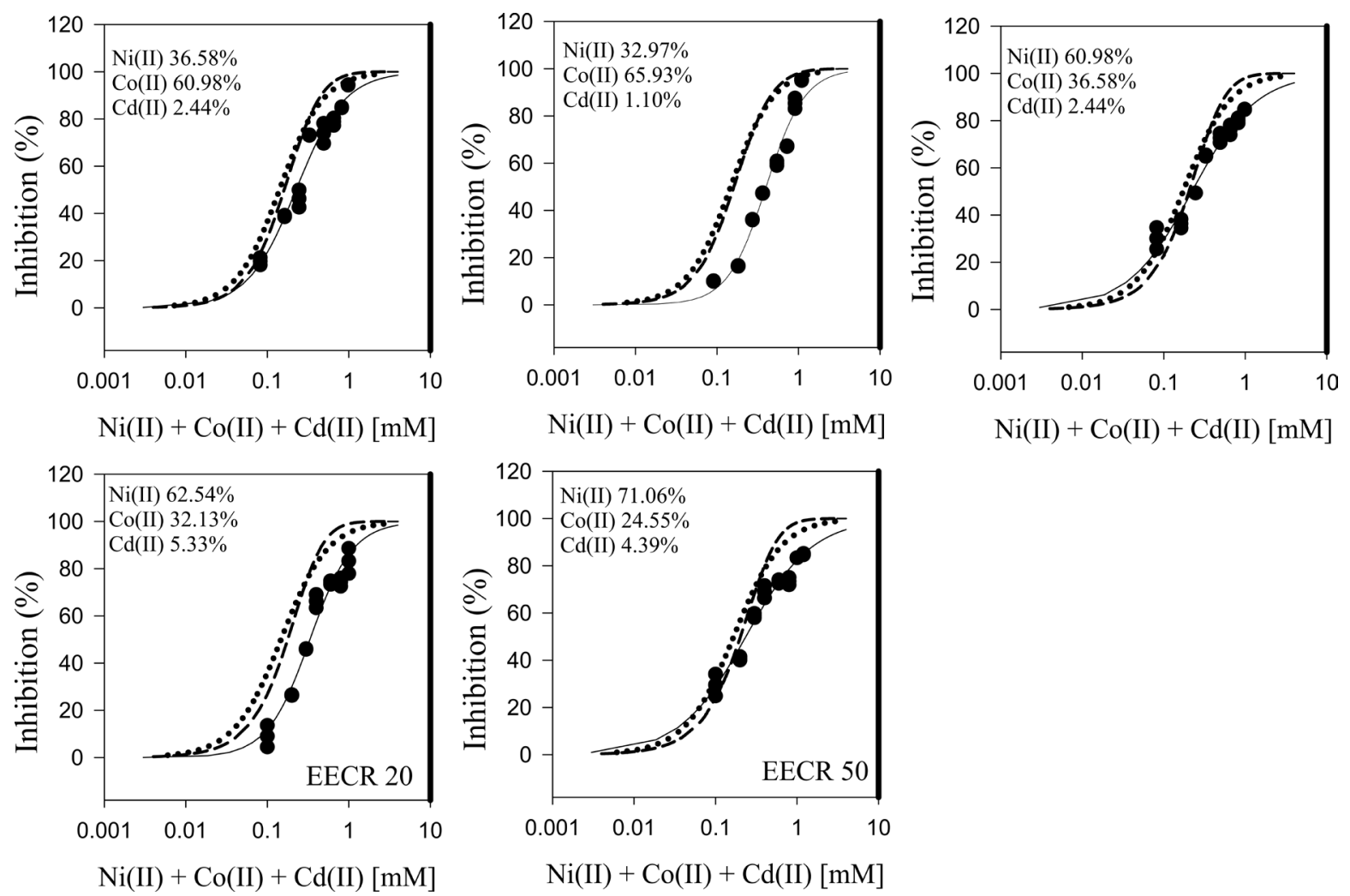

Figure 6: Observed and predicted inhibitions of Pseudomonas fluorescens dehydrogenase activity by ternary mixtures of nickel, cobalt and cadmium ions. The data points represent experimental dose-response data. Solid lines represent toxicities obtained from fitting experimental data to logistic model (equation 2). The dashed lines represent toxicities predicted from the concentration addition model and the dotted lines represent toxicities predicted from the independent action model. 

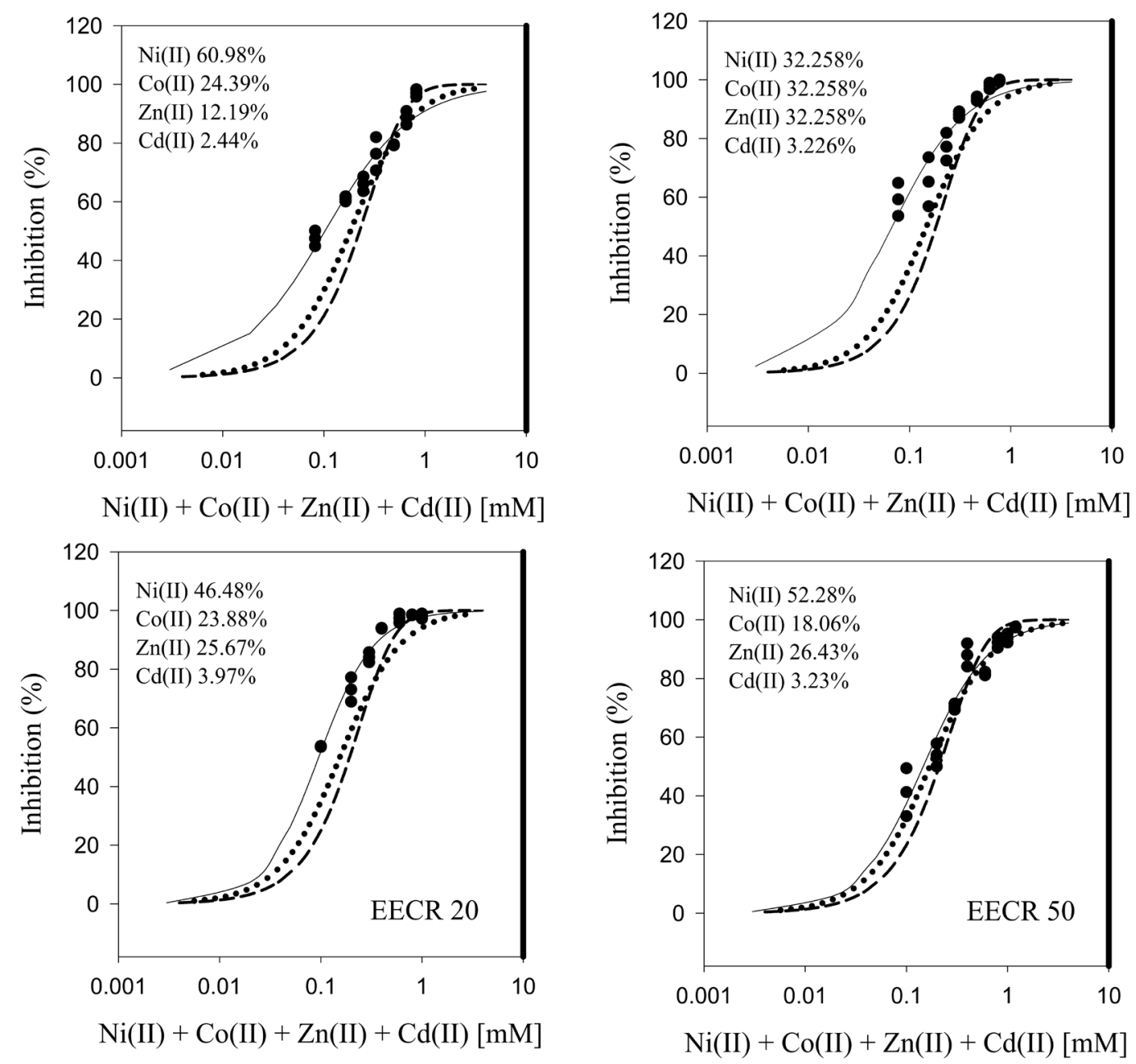

Figure 7: Observed and predicted inhibitions of Pseudomonas fluorescens dehydrogenase activity by quaternary mixtures of nickel, cobalt, zinc and cadmium ions. The data points represent experimental dose-response data. Solid lines represent toxicities obtained from fitting experimental data to logistic model (equation 2). The dashed lines represent toxicities predicted from the concentration addition model and the dotted lines represent toxicities predicted from the independent action model.

of the mixtures respectively. It is worthy of mention that in this study, the CA and IA models predicted identical toxicities of the binary mixtures. Studies have shown that under certain conditions, the toxicity thresholds $\left(\mathrm{EC}_{\mathrm{x}}\right.$ values) predicted by both models may be identical (Boedeker et al., 1993; Drescher \& Boedeker, 1995; Chen et al., 2013; Backhaus et al., 2004; Zhang et al., 2008; Huang, 2011). According to Chen et al. (2013), equal predictions can be produced by $\mathrm{CA}$ and IA models when the dose-response relationship of every individual mixture component can be described by twoparameter Weibull function, the curves are strictly parallel and the slope parameter $\beta$ equals 2.3. Depending on the slope of the individual dose-response relationships, both CA and IA may provide identical prediction (Drescher \& Boedeker, 1995). However, it is important to note also, that according to reports of Cedergreen and co-workers, for binary mixtures of chemicals exhibiting dose-response curves with log-logistic slope parameters around 1, IA and CA predictions are similar (Cedergreen \& Streibig, 2005; Cedergreen et al., 2007; 2008). This seems to be the case in the present study. We used two-parameter logistic model to describe the dose-response relationship of the individual metal ion with slope parameters of $1.172 \pm 0.120,1.263 \pm 0.093,1.770 \pm 0.176$ and $1.596 \pm$ 0.149 for nickel, zinc, cobalt and cadmium ions respectively. These slope parameters are close to 1 and possibly explained the observed similarity between toxicities predicted from CA and IA models for $\mathrm{Ni}(\mathrm{II})+\mathrm{Co}$ (II) and $\mathrm{Zn}$ (II) $+\mathrm{Cd}(\mathrm{II})$ binary mixtures. Similar observation was reported in our previous study involving binary mixtures of phenolic compounds and formulated glyphosate (Nweke et al., 2015). Barata et al. (2006) reported similar predictions by CA and IA models for binary mixtures of metal and pyrethroid insecticides against Daphnia magna. Thus it appears that this behaviour could be extended to mixtures of more than two components. This was also verified in the present study. The values of $\mathrm{EC}_{50}$ predicted for ternary and quaternary mixtures from $\mathrm{CA}$ model are not too far from $\mathrm{EC}_{50}$ predicted from IA model. The ratio of CA-EC to IA-EC $\mathrm{E}_{50}$ varied between 0.911 and 0.946 with an average of 0.931 and standard deviation of 0.013 for $\mathrm{Ni}(\mathrm{II})+\mathrm{Co}(\mathrm{II})+$ $\mathrm{Cd}(\mathrm{II})$ ternary mixture. Similarly, the $\mathrm{Zn}(\mathrm{II})+\mathrm{Cd}(\mathrm{II})+\mathrm{Ni}(\mathrm{II})$ 


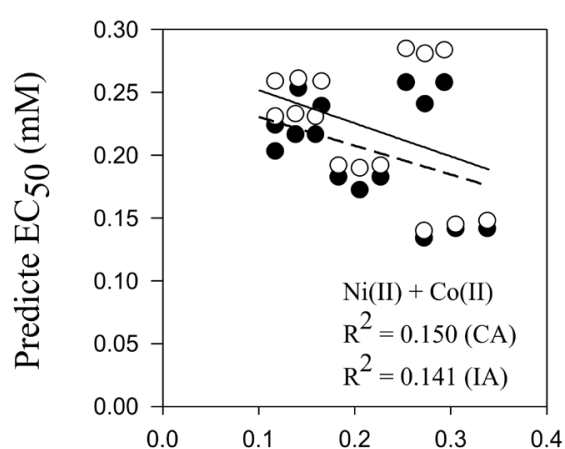

Observed EC $50(\mathrm{mM})$

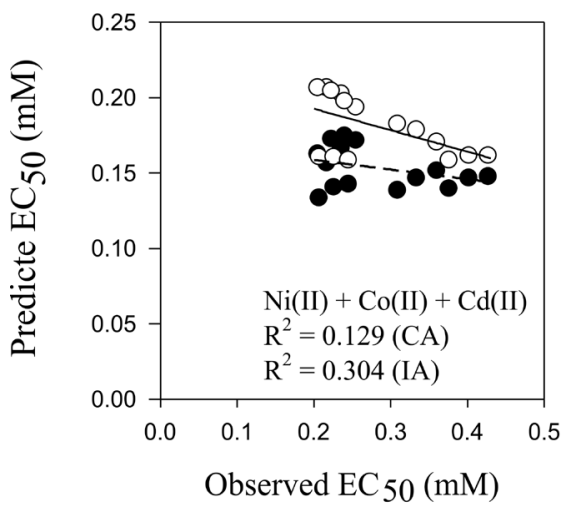

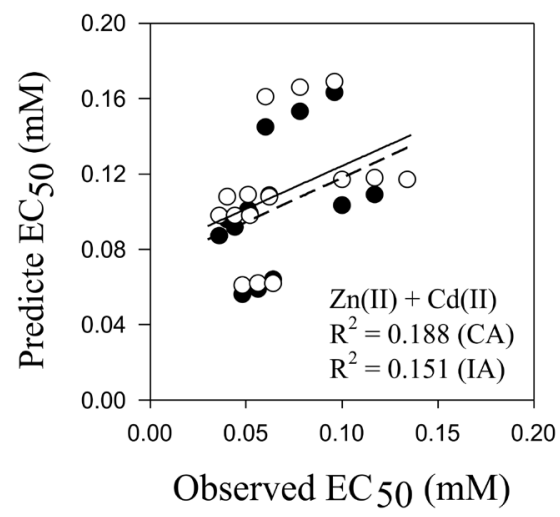
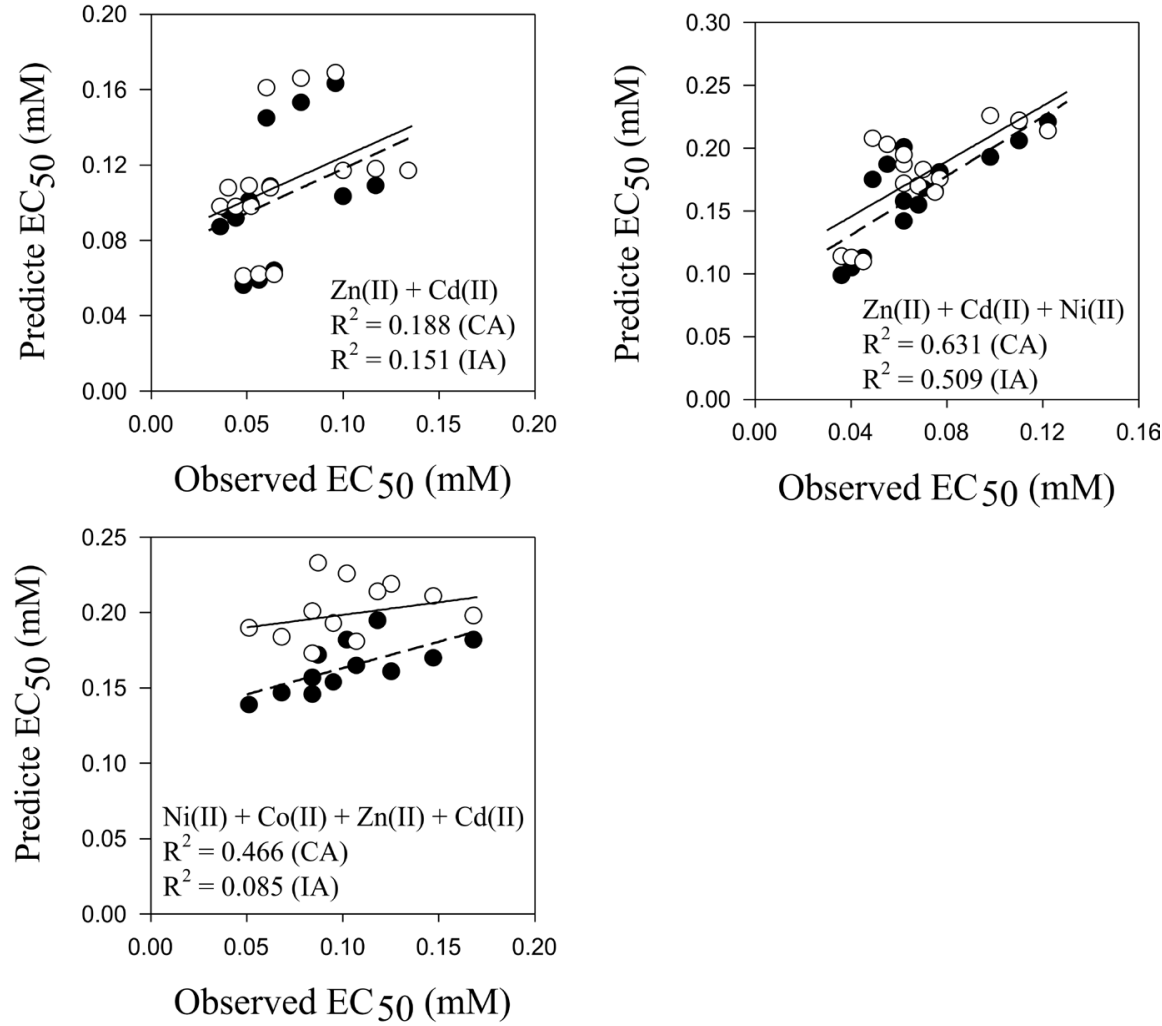

Figure 8: Correlation between the observed and predicted $E C_{50} s$ of the metal ion mixtures. The closed circle represents $\mathrm{CA}$ and the open circle represents the IA data. The dashed and solid lines represent the linear regression of the CA and IA data respectively.

ternary mixture and $\mathrm{Ni}(\mathrm{II})+\mathrm{Co}(\mathrm{II})+\mathrm{Zn}(\mathrm{II})+\mathrm{Cd}(\mathrm{II})$ quaternary mixture had average ratio of 0.850 and 0.821 respectively and corresponding standard deviation of 0.035 and 0.017 . This indicated that CA and IA models may have similar capability in predicting toxicity of the metal mixtures. Insignificant difference between CA- and IA-predicted toxicity of mixtures of phenolic compounds with similar and dissimilar mode of action was reported by Huang et al. (2011). From the view point of the analyses in this study, synergistic, antagonistic and additive effect of binary, ternary and quaternary mixtures of metal ions against $P$. fluorescens could be possible. This underlines the ecological risk of environmental contamination with the mixtures. Synergistic interaction of these metal ions could be of serious concern.

\section{CONCLUSION}

Inhibition of dehydrogenase activity was used to assess toxicity of binary, ternary and quaternary combinations of nickel, cobalt, zinc and cadmium ions against $P$. fluorescens. The experiments were designed to expose the bacterium to varying doses of metal ions, which increased along fixed ratio ray based on uniform design and equieffect concentration ratios. The analyses of the experimental data indicated that the metal mixtures exhibited additive and interactive effects. The CA and IA models predicted identical or nearly identical toxicities. Generally, CA model predicted higher toxicities than IA predictions would suggest, which were not greater than 1.3 fold. However, most toxic index (TI) and model deviation ratios (MDR) between predicted and experimentally observed effect concentrations were between 0.5 and 2.0 and were within the expected inter-laboratory/inter-experiment deviation for most species. Although the results reported in this study cannot be easily extended to other organisms, it provides information on the potential synergistic toxicity of metal mixtures to bacteria. Further research is recommended to extend this investigation to natural microbial communities of aquatic and terrestrial ecosystems.

\section{REFERENCES}

ALTENBURGER, R., BACKHAUS, T., BOEDEKER, W., FAUST, M., SCHOLZE, M. \& GRIMME, L.H. 2000. Predictability of the toxicity of multiple chemical mixtures to Vibrio fischeri: mixtures composed of similarly acting chemicals. Environ. Toxicol. Chem. 19(9): 2341-2347. http://dx.doi.org/10.1002/ etc. 5620190926

AINSWORTH, M.A., TOMPSETT, C.P. \& DEAN, A.C.R. 1980. Cobalt and nickel sensitivity and tolerance in Klebsiella pneumonia. Microbios. 27: 175 - 184.

AWASTHI, M. 2012. Relevance of alkaline phosphatase activity of immobilized green algae and cyanobacteria for heavy metal toxicity monitoring. J. Mater. Environ. Sci. 3(3): 446 - 451.

BACKHAUS T., ALTENBURGER, R. BOEDEKER, W. FAUST, M. SCHOLZE, M, \& GRIMME, L. H,. 2000 Predictability of the toxicity of a multiple mixture of dissimilarly acting chemicals to Vibrio fischeri. Environ. Toxicol. and Chem. 19(9): 2348 - 2356. http://dx.doi.org/10.1002/etc.5620190927 
BACKHAUS, T., FAUST, M., SCHOLZE, M., GRAMATICA, P., VIGHI, M. \& GRIMME, L.H. 2004. Joint algal toxicity of phenylurea herbicides is equally predictable by concentration addition and independent action. Environ. Toxicol. Chem. 23: 258-264. http://dx.doi.org/10.1897/02-497

BARABASZ, W., HETMANSKA, B. \& TOMASIK, P. 1990. The metal-metal interactions in biological systems. Part I. Escherichia coli. Water Air Soil Pollut. 52:337-357. http:// dx.doi.org/10.1007/BF00229442

BARATA, C., BAIRD, D.J., NOGUEIRA, A.J.A., SOARES, A., \& RIVA, M.C., 2006. Toxicity of binary mixtures of metals and pyrethroid insecticides to Daphnia magna Straus: Implications for multi-substance risks assessment. Aquat. Toxicol. 78: $1-14$.

BARNHART C. L.H. \& VESTAL J.R. 1983. Effects of environmental toxicants on metabolic activity of natural microbial communities. Appl. Environ. Microbiol. 46: 970 - 977.

BERENBAUM, M. 1985. The expected effect of a combination of agents: the general solution. J. Theor. Biol. 114: 413 - 431. http://dx.doi.org/10.1080/104084409027875925.

BITTON, G., KOOPMAN, B. \& AGAMI, O. 1992. MetPAD ${ }^{\mathrm{TM}}$ : a bioassay for rapid assessment of heavy metal toxicity in wastewater. Water Environ. Res. 64:834 - 836. http://dx.doi. org/10.1002/0471717967

BOEDEKER,W., DRESCHER, K., ALTENBURGER, R., FAUST, M. \& GRIMME, L.H. 1993. Combined effects of toxicants: the need and soundness of assessment approaches in ecotoxicology. Sci. Total Environ. 134 (2): 931 - 939. http://dx.doi. org/10.1002/etc. 2802

BOILLOT, C., \& PERRODIN, Y. 2008. Joint-action ecotoxicity of binary mixtures of glutaraldehyde and surfactants used in hospitals: use of the Toxicity Index model and isobologram representation. Ecotoxicol. Environ. Saf., 71: 252 - 259. http:// dx.doi.org/10.1016/j.ecoenv.2007.08.010

BRUINS, M.R., KAPIL, S. \& OEHME F.W. 2000. Microbial resistance to metals in the environment. Ecotoxicol.and Environ Saf. 45: 198 - 207. http://dx.doi.org/10.1006/eesa.1999.1860.

BUGG, T., FOGHT, J.M., PICKARD, M.A. \& GRAY, M.R., 2000. Uptake and active efflux of polycyclic aromatic hydrocarbons by Pseudomonas fluorescens Lp6a. Appl. Environ Microbiol. 66 (12): 5387 - 5392. http://dx.doi.org/10.1128/AEM.66.12.53875392.2000

CEDERGREEN, N, \& STREIBIG, J.C. 2005. Can the choice of endpoint lead to contradicting results of mixture toxicity experiments? Environ. Toxicol. Chem. 24:1676 - 1683. http:// dx.doi.org/10.1897/04-362R.1

CEDERGREEN, N., KUDSK, P., MATTHIASEN, S, \& STREIBIG, J.C. 2007. Combination effects of herbicides: Do species and test system matter? Pestic. Manag. Sci. 63: 282 - 295. http://dx.doi. org/10.1002/ps.1353

CEDERGREEN, N., CHRISTENSEN, A.M. KAMPER, A. KUDSK, P., MATHIASSEN, S. K., STREIBIG J. C. \& SØRENSEN, H. 2008. A review of independent action compared to concentration addition as reference models for mixtures of compounds with different molecular target sites. Environ. Toxicol. Chem. 27(7): 1621 - 1632. http://dx.doi.org/10.1897/07-474.

CHANDY, J.P. 1999. Heavy metal tolerance in chromogenic and non-chromogenic marine bacteria from Arabian Gulf. Environ. Monit. Assess. 59: 321 - 330. http://dx.doi. org/10.1023/A:1006173722510

CHEN B.-Y., WU C.-H., \& CHANG J.-S. 2005. An assessment of the toxicology of metals to Pseudomonas aeruginosa PU21 (Rip64), Bioresour. Technol. 97 (15): 1880 - 1886. https://doi. org/10.1016/j.biortech.2005.08.022

CHEN J., JIANG, Y., XU, C., YU, L., SUN, D., XU, L., HU, F. \& LI, H. 2013. Comparison of two mathematical prediction models in assessing the toxicity of heavy metal mixtures to the feeding of the nematode Caenorhabditis elegans. Ecotoxicol. and Environ Saf. 94: 73 - 79. http://dx.doi.org/10.1016/j. ecoenv.2013.04.026.

CHRISTOFI, N., HOFFMANN, C. \& TOSH, L. 2002. Hormesis responses of free and immobilized light emitting bacteria. Ecotoxicol. Environ. Saf. 52(3): 227-231. http://dx.doi. org/10.1006/eesa.2002.2203,

CHU, K.W., CHAN, S.K.W. \& CHOW, K.L. 2005. Improvement of heavy metal stress and toxicity assays by coupling a transgenic reporter in a mutant nematode strain. Aquat. Toxicol. 74: $320-$ 332. http://dx.doi.org/10.1016/j.aquatox.2005.06.006

CHU, K.W. \& CHOW, K.L., 2002. Synergistic toxicity of multiple heavy metals is revealed by a biological assay using a nematode and its transgenic derivative. Aquat. Toxicol. 61: 53 - 64. http:// dx.doi.org/10.1016/S0166-445X(02)00017-6

COBET, A.B., WIRSEN, C. \& JONES, G.E. 1970. The effect of nickel on a marine bacterium, Arthobacter marinus sp. J. Gen. Microbiol. 62: 159 - 169.

CODINA, J.C., PEREZ-GARCIA, A. \& DE VICENTE, A. 1994. Detection of heavy metal toxicity and genotoxicity in wastewaters by microbial assay, Water Sci. Technol. 30 (10): 145 - 151.

DRESCHER, K. \& BOEDEKER, W. 1995. Assessment of the combined effects of substances: The relationship between concentration addition and independent action. Biometrics 51(2): 716 -730. http://dx.doi.org/10.2307/2532957

FAUST, M., ALTENBURGER, R., BACKHAUS, T., BLANCK, H., BOEDEKER, W., GRAMATICA, P., HAMMER, V., SCHOLZE, M., VIGHI, M. \& GRIMME, L.H., 2003. Joint algal toxicity of 16 dissimilar acting chemicals is predictable by the concept of independent action. Aquat. Toxicol., 63, $43-63$. http://dx.doi.org/10.1016/S0166-445X(02)00133-9

FULLADOSA, E., MURAT, J-C., BOLLINGER, J-C. \& VILLAESCUSA I. 2007. Adverse effects of organic arsenical compounds towards Vibrio fischeri bacteria. Sci. Total Environ., 377(2-3): 207 - 213. http://dx.doi.org/10.1016/j. scitotenv.2006.12.044

FULlADOSA, E., MURAT, J-C. \& VILlAESCUSA, I. 2005. Study on the toxicity of binary equitoxic mixtures of metals using the luminescent bacteria Vibrio fischeri as a biological target. Chemosphere, 58: 551 - 557. http://dx.doi.org/10.1016/j. chemosphere.2004.08.007

GADD G.M. 1993. Interactions of fungi with toxic metals. New Phytol. 124: 25-60.

GANESHAN, G. \& KUMAR, A. M. 2005. Pseudomonas fluorescens, a potential bacteria antagonist to control plant diseases. J. Plant Interac. 1(3): 123 - 134. http://dx.doi. org/10.1080/17429140600907043

GE, H-L., LIU S-S, SU B-X \& QIN L-T. 2014. Predicting synergistic toxicity of heavy metals and ionic liquids on photobacterium Q67. Journal of Hazardous Materials 268:77 - 83. http:// dx.doi.org/10.1016/j.jhazmat.2014.01.006

GIKAS, P. 2007. Kinetic responses of activated sludge to individual and joint nickel $(\mathrm{Ni}(\mathrm{II}))$ and cobalt $(\mathrm{Co}(\mathrm{II}))$ : An isobolographic approach. Journal of Hazardous Materials 143: 246 - 256. http:// dx.doi.org/10.1016/j.jhazmat.2006.09.019

GIKAS, P. 2008. Single and combined effects of Nickel and cobalt ions on activated sludge and on other aerobic microorganism: A review. Journal of Harzard materials 159: 187 - 203. http:// dx.doi.org/10.1016/j.jhazmat.2008.02.048 
GUCKERT, J.B. 1996. Toxicity assessment by community analysis. J. Microbiol. Methods, 25: 101-112.

HUANG, W. Y., LIU, F., LIU, S. S., GE, H. L., \& CHEN, H. H. 2011, Predicting mixture toxicity of seven phenolic compounds with similar and dissimilar actionmechanisms to Vibrio qinghaiensis sp.nov.Q67. Ecotoxicol. Environ. Saf. 74 (6): 1600 - 1606. http://dx.doi.org/10.1016/j.ecoenv.2011.01.007

INCE N.H., DIRILGEN, N., APIKYAN, I.G. TEZCANLI, G. \& ÜSTÜN, I.B. 1999. Assessment of Toxic Interactions of Heavy Metals in Binary Mixtures: A Statistical Approach Arch. Environ. Contam. Toxicol. 36: 365 - 372. http://dx.doi.org/10.1007/ PL00006607

JANSEN E., MICHELS, M. H. A., VAN TIL, M. \& DOELMAN, P.1994. Effects of heavy metals in soil microbial diversity and activity as shown by the sensitivity-resistance index, an ecologically relevant parameter. Biol. Fertil. Soil 17: $177-184$. http://dx.doi.org/10.1007/BF00336319

JULIASTUTI, S.R., BAEYENS, J., CREEMERS, C., BIXIO, B. \& LODEWYCKX, E. 2003. The inhibitory effects of heavy metals and organic compounds on the net maximum specific growth rate of the autotrophic biomass in activated sludge. J. Hazard. Mater. 100: $71-283$.

LI,Y., ZHANG, B., HE X., CHENG, W-H., XU, W., LUO, Y., LIANG, R., LUO, H. \& HUANG, K., 2014, Analysis of individual and combined effects of ochratoxin A and zearalenone on HepG2 and KK-1 cells with mathematical models. Toxins 6: $1177-1192$.

MCCARTY, L.S., \& BORGERT, C. J. 2006. Review of toxicity of chemical mixtures: Theory, Policy and Regulatory Practice. Regul. Toxicol. Pharmacol. 36: $198-210$.

NIES, D.H. 1992. Resistance to Cadmium, Cobalt, Zinc, and Nickel in Microbes. Plasmid 27: $17-28$.

NIES, D.H. 1999. Microbial heavy-metal resistance. Appl. Microbiol. Biotechnol. 51: 730 - 750.

NWEKE, C.O., OKOLO, J.C. NWANYANWU, C.E. \& ALISI, C.S. 2006. Response of planktonic bacteria of New Calabar River to zinc stress. Afr. J. Biotechnol. 5(8): 653 - 658. http://dx.doi. org/10.5897/AJB06.128.

NWEKE, C.O., ALISI, C.S., OKOLO, J.C. \& NWANYANWU, C.E. 2007a. Toxicity of zinc to heterotrophic bacteria from a tropical river sediment. Applied Ecology and Environmental Research. 5(1): 123 - 132. http://dx.doi.org/10.15666/aeer/0501_123132.

NWEKE, C.O., NTINUGWA, C., OBAH, I.F., IKE, S.C. EME, G.E., OPARA, E.C., OKOLO, J.C. \& NWANYANWU, C.E. $2007 \mathrm{~b}$. In vitro effects of metals and pesticides on dehydrogenase activity in microbial community of cowpea (Vigna unguiculata) rhizoplane. Afr. J. Biotechnol. 6(3): $290-295$.

NWEKE, C.O. \& ORJI, J.C. 2009. Toxicity of heavy metals to microbial community of New Calabar River. Nig. J. Biochem. Mol. Biol. 24(1): 48 - 54.

NWEKE C.O. \& OKPOKWASILI, G.C. 2012. Kinetics of doseresponse relationship of heavy metals with dehydrogenase activity in wastewater bacteria. J. Res. Biol. 2(4): 392 - 402.

NWEKE, C.O., AHUMIBE, N.C., \& ORJI, J. C., 2014, Toxicity of binary mixtures of formulated Glyphosate and phenols to Rhizobium species dehydrogenase activity. J. Microbiol. Res. 2014, 4(4): 161 - 169. http://dx.doi.org/10.5923/j. microbiology.20140404.02

NWEKE, C.O., ORJI, J.C. \& AHUMIBE, N.C. 2015. Prediction of phenolic compound and formulated glyphosate toxicity in binary mixtures using Rhizobium species dehydrogenase activity. Adv. in Life Sci. 5(2): 27 - 38. http://dx.doi.org/10.5923/j. als.20150502.01
NWEKE C. O., IKE C. C. \& IBEGBULEM C. O. 2016. Toxicity of quaternary mixtures of phenolic compounds and formulated glyphosate to microbial community of river water. Ecotoxicol. Environ. Contam. 11(1): 63 - 71. http://dx.doi.org/10.5132/ eec.2016.01.09

ORJI, J.C., NWEKE, C.O., NWABUEZE, R.N., ANYAEGBU, B., CHUKWU, J.C., CHUKWUEKE, C.P. \& NWANYANWU, C.E. 2008. Impacts of some divalent cations on periplasmic nitrate reductase and dehydrogenase enzymes of Escherichia, Pseudomonas and Acinetobacter species. Revista Ambiente e Água 3(2): 5 - 18.

OSMAN, M.E.H., EL-NAGGAR, A.H., EL-SHEEKH, M.M. \& EL MAZALLY, E.E. 2004. Differential Effects of $\mathrm{Co}^{2+}$ and $\mathrm{Ni}^{2+}$ on protein metabolism in Scenedesmus obliquus and Nizschia perminuta, Environ. Toxicol. Pharmacol. 16:169 - 178. http:// dx.doi.org/10.1016/j.etap.2003.12.004

PETERSEN, K. \& TOLLEFSEN, K.E. 2011. Assessing combined toxicity of estrogen receptor agonists in a primary culture of rainbow trout (Oncorhynchus mykiss) hepatocytes. Aquat. Toxicol. 101: 186 - 195. http://dx.doi.org/10.1016/j. aquatox.2010.09.018

PRESTON, S., NICHOLAS, C., TOWNEND, J., KILLHAM, K. \& PATON, G. 2000. Biosensing the acute toxicity of metal interactions: are they additive, synergistic, or antagonistic. Environmental Toxicology and Chemistry 19(3): $775-780$. http://dx.doi.org/10.1002/etc.5620190332

RAI, L.C. \& RAIZADA M. (1986), Nickel induced stimulation of growth, heterocyst differentiation, ${ }^{14} \mathrm{CO}_{2}$ uptake and nitrogenase activity in Nostoc muscorum, New Phytol. 104: 111-114. http:// dx.doi.org/10.1111/j.1469-8137.1986.tb00638.

REN, S. \& FRYMIER, P.D. 2003. Kinetics of the toxicity of metals to luminescent bacteria. Adv. Environ. Res. 7:537 - 547.

RICHARD, J.Y. \& VOGEL, T.M., 1999. Characterisation of a soil bacterial consortium capable of degrading diesel fuel. International Biodeterioration and Biodegradation 44: 93 - 100. http://dx.doi.org/10.1016/S0964-8305(99)00062-1

RODEA-PALOMARES, I., GONZALEZ-GARCIA, C., LEGANES F. \& FERNANDEZ-PINAS, F. 2009. Effect of pH, EDTA, and anions on heavy metal toxicity toward a bioluminescent Cyanobacterial bioreporter. Arch. Environ. Contam. Toxicol. 57(3):477 - 487. http://dx.doi.org/10.1007/s00244-008-9280-9

SIVASAKTHI, S., KANCHANA, D., USHARANI, G. \& SARANRAJ, P. 2013. Production of plant growth promoting substance by Pseudomonas'fluorescens and Bacillus subtilis isolates from paddy rhizosphere soil of Cuddalore district, Tamil Nadu, India. Int. J. Microbiol. Res. 4(3): 227 - 233. http://dx.doi. org/10.5829/idosi.ijmr.2013.4.3.75171

VISCA, P., COLOTTI, G., SERINO, L., VERZILI D., ORSI N. \& CHIANCONE, E. 1992. Metal regulation of siderophore synthesis in Pseudomonas aeruginosa and functional effects of siderophore-metal complexes, Appl. Environ. Microbiol. 58 (9): $2886-2893$.

WOOD J. M. \& WANG H. K. 1983. Microbial Resistance to Heavy Metals. Environmental Science and Technology 17: 582 - 590.

XU X., LI Y., WANG Y. \& WANG Y. 2011. Assessment of toxic interactions of heavy metals in multi-component mixtures using sea urchin embryo-larval bioassay Toxicology In vitro 25: 294300. http://dx.doi.org/10.1016/j.tiv.2010.09.007

ZHANG, Y.H., LIU, S.S., SONG, X.Q. \& GE, H.L. 2008. Prediction for the mixture toxicity of six organophosphorus pesticides to the luminescent bacterium q67. Ecotoxicol. Environ. Saf. 71, $880-$ 888. http://dx.doi.org/10.1016/j.ecoenv.2008.01.014 